Research Article

\title{
Soil Moisture Response to Short-Term Inorganic Fertilization on Tef (Eragrostis tef (Zucc.) Trotter) Crop Varieties in Northern Ethiopia
}

\author{
Gebreyesus Brhane Tesfahunegn \\ College of Agriculture, Aksum University, Shire Campus, P.O. Box 314, Shire, Ethiopia \\ Correspondence should be addressed to Gebreyesus Brhane Tesfahunegn; gebre33@gmail.com
}

Received 15 October 2018; Revised 29 April 2019; Accepted 3 June 2019; Published 24 June 2019

Academic Editor: Rafael Clemente

Copyright (c) 2019 Gebreyesus Brhane Tesfahunegn. This is an open access article distributed under the Creative Commons Attribution License, which permits unrestricted use, distribution, and reproduction in any medium, provided the original work is properly cited.

\begin{abstract}
Little is known about soil nutrient practice effects on soil moisture under cereal cropping systems. The objective of this research was to evaluate soil moisture content (SMC) response to short-term nitrogen (N) and phosphorus (P) fertilizer rates applied on tef crop varieties and their interactions. A rain-fed fertilizer experiment using tef varieties as the test crop was conducted for two years (2012-2013) in the Chromic Cambisols of northern Ethiopia. The experimental design was laid down in randomized complete block design with three replications. Two treatment factors, namely, fertilizer (four $\mathrm{N}+\mathrm{P}$ rates) and variety (three tef varieties), were tested. Soil samples were taken at different tef crop growth stages or days after sowing time (DAS) to determine SMC using the gravimetric method. Data were analyzed at a probability level of 0.05 . The fertilizer treatments significantly affected the SMC determined at the different tef growth stages and cropping seasons. The highest SMC was determined at $33 \mathrm{DAS}\left(51 \mathrm{~m}^{3} \cdot \mathrm{m}^{-3}\right)$, but SMC decreased with increasing fertilizer rates. A higher SMC response to local tef variety than improved variety was found across all the growth stages and cropping seasons. There were also significant differences in SMC among the treatment interactions determined at the different growth stages and across the years. The paired mean differences in SMC due to the treatments between the two years were strongly correlated $(r>0.90, P=0.001)$. For SMC response being effective to fertilizer and its interaction effect with variety, it is suggested that soil management practices that improve moisture such as organic sources should be integrated with the inorganic fertilizer in the conditions of Chromic Cambisols in northern Ethiopia.
\end{abstract}

\section{Introduction}

Tef (Eragrostis tef (Zucc.) Trotter) is Ethiopian domesticated cereal crop which grows widely under diverse environmental conditions, i.e., from the sea level up to $2800 \mathrm{~m}$ above the sea level under a range of rainfall, temperature, and soil conditions $[1,2]$. This crop covers $29 \%$ of the total cereal production areas and is a staple food for more than 50 million people in Ethiopia [3]. Since a decade ago, tef crops have also been introduced globally to several countries (e.g., USA, Australia, India, Eritrea, and Kenya) because of its gluten-free high nutritional and market values for different purposes [4]. Despite such expansion and demand of tef crops, the average yield of tef $\left(<1 \mathrm{t} \cdot \mathrm{ha}^{-1}\right)$ in Ethiopia is lower than the other cereals, which is partly attributed to low soil moisture availability $[2,5]$. Continuous cultivation for many years with no or little addition of organic fertilizer sources has aggravated soils to have poor soil structure and low soil moisture holding capacity $[2,5,6]$.

Previous researchers have reported that losses in soil properties such as soil structure and soil nutrients through erosion and soil nutrients with crop harvest when farmers were unable to compensate for these losses have aggravated the problem of soil moisture and nutrient availability for crop growth and development [5-7]. The removal of organic matter-rich topsoil continuously by erosion is more severe on overcultivated soils which has resulted in poor soil structure and infiltration and thereby poor soil moisture holding capacity. Such poor soil characteristics make water a key limiting factor for crop production 
especially with fertilizer application in the conditions of northern Ethiopia [2,8]. Insufficient soil moisture availability of fertilized fields has suggested that there is a need for introducing management options that improve moisture and thereby tef crop productivity per unit area. Understanding the effects of soil management options such as organic and inorganic fertilizer rates on soil moisture retention and utilization of tef crop varieties in the short and long term is crucial [6-8].

In the dry land condition of the northern Ethiopia, moisture stress at crop establishment and grain filling stages are frequently reported, mainly in the fields treated with fertilizer. This could be due to the fact that fertilized field crops use more soil water at the grain filling stage than unfertilized plots. Soil moisture management practices targeting to improve crop production at these stages could be the main concern of farmers in the dry land areas $[2,8]$. Weather variability and unpredictability (erratic nature of rainfall) have challenged previous efforts of fertilizer technology (e.g., blanket fertilizer recommendation) when it has been attempted to improve the yield of tef $[2,7]$.

Soil water deficit (low soil moisture) remains the most frequently noted critical challenge for being less effective of the recommended blanket fertilizer rate in moisture stressed (high risk) areas such as the northern Ethiopia. Low soil moisture that limits soil nutrients availability and efficiency (poor response) has been reported as a key challenge for fertilizer adoption by farmers. Such unfavorable effects of soil moisture on the fertilizer technology adoption can be minimized using suitable agronomic practices that improve soil moisture such as ridge construction, using organic fertilizer, and/or adoption of moisture stress tolerant crop varieties $[2,8,9]$. The effects of soil moisture stress on crop production vary with soil types, tillage frequency and type, fertilizer rates, crop growth stages, and crop types and varieties. Agricultural practices and efforts in dry land areas such as the northern Ethiopia must be directed towards the improvement of soil moisture availability for sustainable crop production by smallholder farmers using a combination of the above agronomic practices $[6,9,10]$.

Previous studies have given due attention almost exclusively to the effects of fertilizer rates and varieties on the crop yield in the conditions of Vertisols (e.g., $[8,11])$ and on long-term statuses of some soil physical (other than soil moisture) and chemical properties (e.g., $[12,13])$. Past reports have also shown that long-term continuous use of inorganic fertilizers lead to nutrient imbalances or deterioration in soil chemical, physical, and biological properties $[10,12,13]$. However, there have been little documented scientific evidences on soil moisture content (SMC) response to short-term effects of soil and crop management practices in the conditions of Chromic Cambisols. Thus, the objective of this study was to evaluate the response of SMC to the short-term effects of $\mathrm{N}$ and $\mathrm{P}$ inorganic fertilizer rates, crop varieties, and their interactions executed successively for two years (2012-2013) in Chromic Cambisols in the northern Ethiopia condition.

\section{Materials and Methods}

2.1. Study Site Description. A rain-fed fertilizer experiment using tef varieties as the test crop was conducted for consecutive two years (2012-2013) in Dura Farmers Training Center $\left(14^{\circ} 07^{\prime} \mathrm{N}\right.$ latitude and $38^{\circ} 44^{\prime} \mathrm{E}$ longitude). It is an administrative unit of the Tigray region, northern Ethiopia. The experimental site was located at an altitude and slope of $2050 \mathrm{~m}$ and $2 \%$, respectively. For the trial site, 30-year average annual rainfall and temperature of $680 \mathrm{~mm}$ and $20^{\circ} \mathrm{C}$, respectively, were recorded. The pattern of rainfall is unimodal with the main rainy season from July to early September (Figure 1). However, more than $70 \%$ of the annual rainfall was recorded in the months of July and August (source: Ethiopia Meteorology Agency, Mekelle Branch).

The trial site received 116,83 , and $147 \mathrm{~mm}$ rainfall before sowing time in 2012, 2013, and 30-year average, respectively. The trial received 525,450 , and $560 \mathrm{~mm}$ of rainfall between sowing and harvesting time in 2012, 2013, and 30-year average, respectively. Rainfall was higher thus in 2012 when compared with the 2013 crop season and the 30-year average. The peak rainfall amount was observed in August across all the cropping seasons (Figure 1).

2.2. Experimental Design, Treatments, and Procedures. The experimental design was laid down in factorial randomized complete block design, with three replications. The treatments were applied to the same experimental plots in both successive years (2012-2013). Two factorial treatments, namely, fertilizer rates $(F)$ and tef varieties $(V)$ were evaluated during the experimental periods. The first factor consisted of four fertilizer rates applied as $\mathrm{N}+\mathrm{P}(\mathrm{N}$ plus $\mathrm{P}$ in $\mathrm{kg} \cdot \mathrm{ha}^{-1}$ ). These were $0 \mathrm{~N}+0 \mathrm{P}$ (F1), $21 \mathrm{~N}+10 \mathrm{P}$ (F2), 41 $\mathrm{N}+20 \mathrm{P}$ (F3), and $64 \mathrm{~N}+25 \mathrm{P}$ (F4). The second factor included the three tef varieties, namely, Sergen (V1), DZ-cr387 or Kuncho (V2), and Keyih (V3). V1 and V3 are local varieties, whereas V2 is improved variety. The total treatment combinations or interactions were 12, i.e., 4 fertilizer rates $\times 3$ varieties $(\mathrm{F} 1 \mathrm{~V} 1, \mathrm{~F} 1 \mathrm{~V} 2, \mathrm{~F} 1 \mathrm{~V} 3, \mathrm{~F} 2 \mathrm{~V} 1, \mathrm{~F} 2 \mathrm{~V} 2, \mathrm{~F} 2 \mathrm{~V} 3$, F3V1, F3V2, F3V3, F4V1, F4V2, and F4V3). These treatments were applied on a plot size of $3 \mathrm{~m} \times 4 \mathrm{~m}$ using the simple random technique. This size of the experimental plot was used in order to reduce the effect of external factors that induce variability among the plots within a given block. As the plot size increases, its homogeneity is expected to decrease and so contributes to increase the source of error. The spacing between blocks and plots was 2.0 and $1.5 \mathrm{~m}$, respectively. The treatments were applied after plowing three times using the traditional plowing system of oxen-drawn local implement known as maresha. The tillage frequency and other practices for the experimental site were similar to that of local farmers. The previous crop of the experimental site was wheat which received the blanket recommended fertilizer rate of $100 \mathrm{~kg} \cdot \mathrm{ha}^{-1}$ diammonium phosphate (DAP) and $100 \mathrm{~kg} \cdot \mathrm{ha}^{-1}$ urea. Assuming that interaction between main effects $(F, V)$ and blocks $(B)$ are zero and are pooled into the total error term, the experimental model is given as follows: 


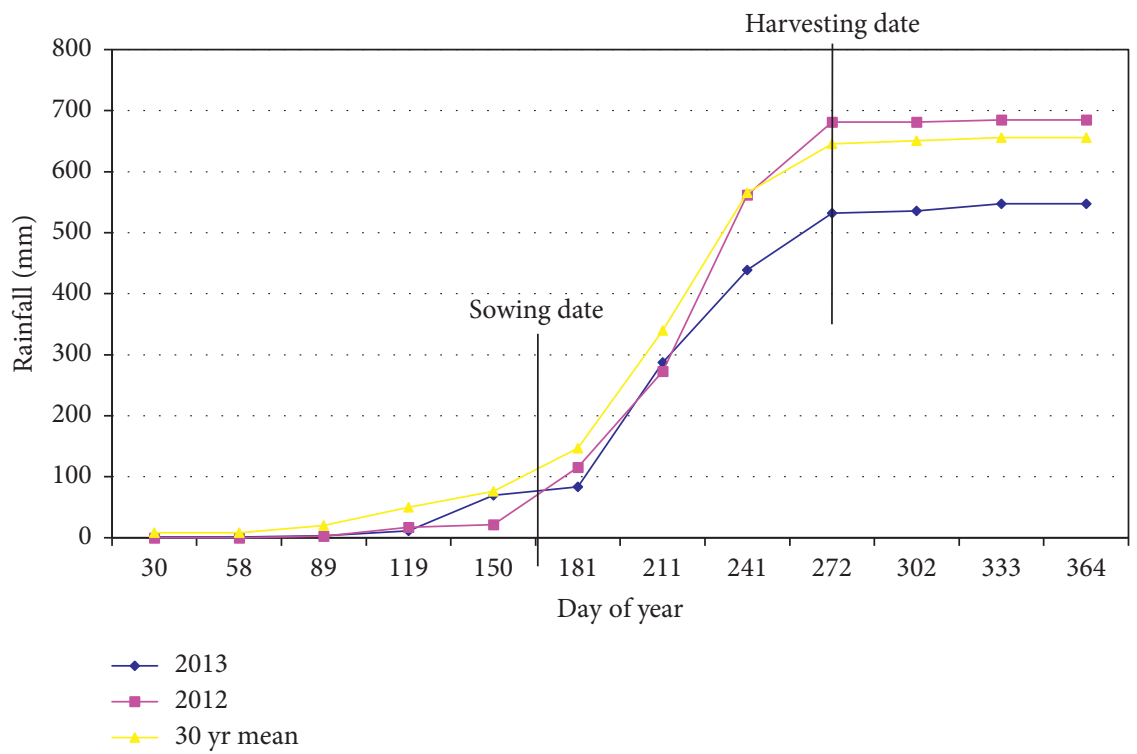

FIGURE 1: Cumulative rainfall across the two cropping seasons (2012 and 2013) and average of 30 years for the trial site in the Dura area, northern Ethiopia.

$$
Y_{i j k}=\mu+F_{i}+V_{j}+F V_{i j}+B_{k}+\text { error, }
$$

where $Y_{i j k}$ is the soil moisture observation for which $i$ and $j$ are reflected for the main treatment factors and $k$ is for the blocking factor, $\mu$ is the mean, $F_{i}$ is the effect due to fertilizer $i, V_{j}$ is the effect due to variety $j, F V_{i j}$ is the interaction effect due to fertilizer and variety $i j$, and $B_{k}$ is the effect due to block $k$.

All plots were compacted by trampling with human labor, and then seeds of the tef varieties were broadcasted uniformly by hand at a rate of $30 \mathrm{~kg} \cdot \mathrm{ha}^{-1}$. The sources of $\mathrm{P}$ and $\mathrm{N}$ were DAP and urea, respectively. The $\mathrm{N}$ in DAP was also considered during fertilizer application. DAP was broadcasted at planting time and covered by less than $1 \mathrm{~cm}$ soil depth. Urea was top dressed at four weeks after sowing (just immediately after $1^{\text {st }}$ weeding). All plots were weeded twice manually. Dates of all agronomic operations and each crop growth stages are shown in Table 1.

2.3. Soil Sampling, Analysis, and Interpretation. Just at the sowing date (preplanting), three composites of soil samples were collected from the entire experimental site at $0-20 \mathrm{~cm}$ soil depth (plow depth). This depth was considered for sampling as it is the most disturbed depth by conventional plowing. These samples were thoroughly mixed, and a subsample of $500 \mathrm{~g}$ soil was taken and processed to determine soil texture, $\mathrm{pH}$, soil organic carbon (SOC), total nitrogen (TN), and available phosphorus (Pav) following the standard laboratory procedures adopted by Ethiopian $\mathrm{Na}-$ tional Soil Laboratory. Soil bulk density (BD) was determined using three undisturbed soil samples by the core method [14]. The analysis results showed that the soil property analysis result of the experimental site which was determined just at the planting time showed sandy clay loam texture, neutral $\mathrm{pH}$ (7.07), very low OC (0.39\%), low TN
TABle 1: Dates of agronomic practices and different growth stages of tef crops in 2012 and 2013 cropping seasons.

\begin{tabular}{lcc}
\hline Agronomic operation & 2012 & 2013 \\
\hline $1^{\text {st }}$ plowing & 22 May 2012 & 25 May 2013 \\
$2^{\text {nd }}$ plowing & 13 June 2012 & 15 June 2013 \\
$3^{\text {rd }}$ plowing & 8 July 2012 & 9 July 2013 \\
Sowing date & 8 July 2012 & 9 July 2013 \\
$1^{\text {st }}$ hand weeding & 8 Aug 2012 & 9 Aug 2013 \\
$2^{\text {nd }}$ hand weeding & 22 Aug 2012 & 23 Aug 2013 \\
Tillering time & 11 Aug 2012 & 12 Aug 2013 \\
Stem elongation & 27 Aug 2012 & 28 Aug 2013 \\
Booting stage & 10 Sep 2012 & 11 Sep 2013 \\
Grain filling stage & 01 Oct 2012 & 02 Sep 2013 \\
Harvesting time & 8 Nov 2012 & 9 Nov 2013 \\
\hline
\end{tabular}

Note: the growth stages of tef crops were used as the dates to take soil samples and then determine soil moisture content of the experimental plots. All varieties showed almost similar dates of crop growth stages.

(0.05\%), and low Pav (7.6 ppm) as compared to the rates determined for African soils by Landon [15]. The experimental site mean soil BD was $1.65 \mathrm{Mg} \cdot \mathrm{m}^{-3}$ in which this can limit crop root growth.

2.4. Soil Moisture Determination. Three soil samples were collected at the $0-20 \mathrm{~cm}$ soil depth (plow layer) from the boarder $(20 \mathrm{~cm}$ from the plot edge) of each experimental plot planted with tef crops in 2012 and 2013 cropping seasons. The soil samples were collected during the different growth stages of tef crops (days after sowing, DAS) in both cropping seasons, i.e., at sowing, tillering, stem elongation, booting stage, grain filling, and harvesting stage of the tef crop. The corresponded number of days just after sowing (DAS) for each of those growth stages was $0,33,49,64,84$, and 120, respectively. The soil samples collected at the sowing time in 2012 were before imposing any of the treatments. The plow depth where the soil samples are collected is the depth where 
changes in most soil properties are expected to occur due to continous cultivation and the associated effects of the shortterm soil and crop management practices [2]. In addition, tef has dense fibrous roots which concentrate generally at the topsoil depth. Even the root system is found extremely at shallow depth to use soil moisture and nutrients particularly at the early growth stage of the crop $[1,2]$.

The soil samples were taken during the different sampling dates (crop growth stages) and used to determine soil moisture content by the gravimetric method. In this method, soil samples were weighed wet and dried in a forced-air oven at $105^{\circ} \mathrm{C}$ until constant weight was observed. Volumetric soil moisture was calculated as described by Hillel [16]:

$$
\theta_{v}=\left[\left(\frac{\mathrm{SW}_{\mathrm{i}}-\mathrm{SW}_{\mathrm{d}}}{\mathrm{SW}_{\mathrm{d}}}\right)\left(\frac{\rho_{\mathrm{s}}}{\rho_{\mathrm{w}}}\right)\right] \times 100 \%,
$$

where $\theta_{y}$ is the volumetric soil moisture content in \% volume $\left(\mathrm{m}^{3} \cdot \mathrm{m}^{-3}\right), \mathrm{SW}_{\mathrm{i}}$ is the initial weight of the soil $(\mathrm{g}), \mathrm{SW}_{\mathrm{d}}$ is the oven-dry weight of the soil $(\mathrm{g}), \rho_{\mathrm{s}}$ is the dry soil bulk density $\left(\mathrm{Mg} \cdot \mathrm{m}^{-3}\right)$, and $\rho_{\mathrm{w}}$ is the density of water $\left(\mathrm{Mg} \cdot \mathrm{m}^{-3}\right)$. The mean soil moisture content determined at the different sampling dates (growth stages) was recorded for each treatment (separate and interactions) effect across the cropping seasons. Values of soil moisture content at the field capacity, FC $(-3.3 \mathrm{~m})$, and permanent wilting point, PWP $(-150.0 \mathrm{~m})$, suctions of the trial site have already reported by Tesfahunegn [2] following the procedures in Brady and Weil [17]. The FC of 27 and PWP of $12 \mathrm{~m}^{3} \cdot \mathrm{m}^{-3}$ were used in this research while interpreting the soil moisture content determined at the different growth stages of the tef crop with respect to the treatments applied.

\subsection{Additional Biophysical Data Collection and Procedures.} Data on site characterization, e.g., rainfall, temperature, and soil type, were collected from secondary sources. Altitude, latitude and longitude, slope, and previous crop were collected from field measurement and observation.

2.6. Data Analysis. Data were subjected to analysis of variance using Statistix 10 software (Analytical Software, Tallahassee, FL). Treatment effects were considered significant at the 0.05 probability level $(P)$. Mean of the treatment effects was separated using the least significant difference (LSD) at $P \leq 0.05$. Data on soil moisture contents were analyzed for the separate and interaction effects of the treatments on a specific sampling date (the tef crop growth stage) and across each year which was resulted up to fourway interactions. A pooled analysis using the two-year data was also conducted for the separate and interaction treatment effects on SMC determined at the different growth stages (sampling dates). Descriptive statistics was also used for the analysis of SMC data.

Paired-samples $T$-test at $P \leq 0.05$ was used for paired mean difference comparison between values of the same treatments determined at the same sampling date across the two cropping seasons. The paired-samples T-test procedure was used to test the null hypothesis stated as "there was no significant difference in soil moisture contents determined at the same and different sampling dates (crop growth stage) due to the effects of fertilizer rates, tef varieties, and their interactions across the two cropping seasons." Two-tailed correlation analysis $(P \leq 0.05)$ was used to associate between the soil moisture content determined at the different growth stages across the cropping seasons.

\section{Results and Discussion}

3.1. SMC Response to Fertilizer Rates and Tef Varieties in 2012-2013 Cropping Seasons. The analysis of variance of soil moisture content (SMC) response to the main effects (fertilizer and variety) in the 2012 and 2013 cropping seasons is shown in Tables 2 and 3, respectively. The mean SMC determined with respect to the responses to the $\mathrm{N}+\mathrm{P}$ fertilizer rates at the different crop growth stages during the 2012 and 2013 cropping seasons is also shown in Figures 2(a) and 2(b) and Figures 3(a) and 3(b), respectively.

In 2012 crop season, there were significant differences in SMC response to most of the fertilizer rates determined at a given tef crop growth stage and also among the different growth stages. However, the SMC determined at 0 DAS of tef crops did not show any significant differences among the fertilized plots. Such result in SMC was expected because the soil samples determined at sowing time were collected before the treatments were imposed on the plots. There was also nonsignificant difference in SMC response between F2 and F3 at 33 DAS (Figure 2(a)). The highest SMC response to F1 $\left(53 \mathrm{~m}^{3} \cdot \mathrm{m}^{-3}\right)$ was determined at 33 DAS (tillering growth stage) followed by 49 DAS (stem elongation stage). This could be due to the peak rainfall which was recorded during the tillering stage of the crop. The lowest SMC response to F4 $\left(8 \mathrm{~m}^{3} \cdot \mathrm{m}^{-3}\right)$ was determined at 120 DAS (harvesting stage). The highest SMC among the soil sampling dates was determined from the plots treated with F1 followed by F2, whereas the lowest was from F4 in both cropping seasons (Figure 4(a)), and indicates moisture availability is insufficient for being available at the higher rate of fertilizer (e.g., F4) particularly at the moisture stress stages of the crop (flowering and grain filling stages). The plots that received a higher fertilizer rate could consume much soil moisture to give a higher crop biomass and vice versa for a lower fertilizer rate as a short-term effect on soil moisture.

The response of soil moisture content (SMC) to the $\mathrm{N}+\mathrm{P}$ fertilizer rates determined at the different growth stages of the tef crop varieties in 2013 crop season showed significant variability. There were significant differences in SMC determined at 0 DAS between F1 and the other treatments. Such differences in SMC could be attributed to the treatment effects of the previous cropping season (2012) which may favor for F1 to have significantly higher soil moisture than the other treatments at planting time. There were significant differences among all the fertilizer rate effects on SMC determined at 33, $49,64,84$, and 120 DAS in 2013 season. During this year, the highest SMC $\left(48 \mathrm{~m}^{3} \cdot \mathrm{m}^{-3}\right)$ was determined at 33 followed by 49 DAS $\left(44 \mathrm{~m}^{3} \cdot \mathrm{m}^{-3}\right.$ ) (Figures $3(\mathrm{a})$ and $\left.4(\mathrm{a})\right)$. Such trends indicate that the highest SMC was reported from plots treated with no fertilizer. 
TABle 2: Analysis of variance (ANOVA) for fertilizer rates, tef varieties, and their interaction effects on soil moisture determined at the different crop growth stages in northern Ethiopia (2012 cropping season).

\begin{tabular}{lccccc}
\hline Source & DF & SS & MS & $F$ & $P$ \\
\hline ANOVA of soil moisture determined & at sowing time & $(0$ & $D A S)$ & with \\
response to fertilizer, & variety, and their interaction & \\
Replication & 2 & $2.919 \mathrm{E}-29$ & $1.459 \mathrm{E}-29$ & & \\
Fertilizer (F) & 3 & 4.25 & 1.417 & 4.250 & $0.0920^{\mathrm{ns}}$ \\
Variety (V) & 2 & 1.167 & 0.5833 & 1.750 & $0.2302^{\text {ns }}$ \\
F $\times$ V & 6 & 2.222 & 0.3703 & 1.111 & $0.3416^{\text {ns }}$ \\
Error & 24 & 8 & 0.3333 & & \\
Total & 35 & 15.64 & & & \\
\hline
\end{tabular}

ANOVA of soil moisture determined at 33 days after sowing with response to fertilizer, variety, and their interaction

\begin{tabular}{lccccc} 
Replication & 2 & 8.00 & 4.00 & & \\
Fertilizer (F) & 3 & 56.25 & 18.75 & 8.80 & 0.0200 \\
Variety (V) & 2 & 22.39 & 11.20 & 5.256 & $0.0810^{\text {ns }}$ \\
F $\times$ V & 6 & 64.9 & 10.82 & 5.078 & $0.1020^{\text {ns }}$ \\
Error & 22 & 46.89 & 2.130 & & \\
Total & 35 & 190.4 & & & \\
\hline
\end{tabular}

ANOVA of soil moisture determined at 49 days after sowing with response to fertilizer, variety, and their interaction

$\begin{array}{lccccc}\text { Replication } & 2 & 1.500 & 0.750 & & \\ \text { Fertilizer (F) } & 3 & 150 & 50 & 16.11 & 0.0010 \\ \text { Variety (V) } & 2 & 86.38 & 43.19 & 13.92 & 0.0030 \\ \text { F } \times \text { V } & 6 & 298.5 & 49.75 & 16.03 & 0.0010 \\ \text { Error } & 22 & 68.27 & 3.1034 & & \\ \text { Total } & 35 & 603.2 & & & \end{array}$

ANOVA of soil moisture determined at 64 days after sowing with response to fertilizer, variety, and their interaction

$\begin{array}{lccccc}\text { Replication } & 2 & 2.000 & 1.000 & & \\ \text { Fertilizer (F) } & 3 & 284.3 & 94.77 & 22.60 & 0.0002 \\ \text { Variety (V) } & 2 & 61.69 & 30.845 & 7.355 & 0.0300 \\ \text { F } \times \text { V } & 6 & 764.2 & 127.4 & 30.37 & 0.0001 \\ \text { Error } & 22 & 92.28 & 4.194 & & \\ \text { Total } & 35 & 1202.5 & & & \end{array}$

ANOVA of soil moisture determined at 84 days after sowing with response to fertilizer, variety, and their interaction

$\begin{array}{lccccc}\text { Replication } & 2 & 2.000 & 1.000 & & \\ \text { Fertilizer (F) } & 3 & 314.3 & 104.8 & 30.97 & 0.0001 \\ \text { Variety (V) } & 2 & 42.667 & 21.3335 & 6.306 & 0.0350 \\ \text { F } \times \text { V } & 6 & 605 & 100.8 & 29.80 & 0.0001 \\ \text { Error } & 22 & 74.43 & 3.3833 & & \\ \text { Total } & 35 & 1036.4 & & & \end{array}$

ANOVA of soil moisture determined at 120 days after sowing with response to fertilizer, variety, and their interaction

\begin{tabular}{lccccc} 
Replication & 2 & 2.000 & 1.000 & & \\
Fertilizer (F) & 3 & 83 & 27.67 & 6.87 & 0.0321 \\
Variety (V) & 2 & 49.567 & 24.78 & 6.153 & 0.0370 \\
F $\times$ V & 6 & 178.8 & 29.80 & 7.399 & 0.0301 \\
Error & 22 & 88.61 & 4.028 & & \\
Total & 35 & 399.977 & & & \\
\hline
\end{tabular}

$\mathrm{DF}=$ degree of freedom; $\mathrm{SS}=$ sum of squares; $\mathrm{MS}=$ mean squares; $F=$ calculated value (test statistic); $P=$ probability level; $\mathrm{ns}=$ nonsignificant at $P>0.05$.

The trend in SMC due to the separate effects of the tef crop varieties at the different sampling dates was similar with that of the fertilizer rates, with the highest value observed at 33 DAS and the lowest at 120 DAS in both 2012 and 2013 seasons. The highest and lowest SMC were determined at the
TABle 3: Analysis of variance (ANOVA) for fertilizer rates, tef varieties, and their interaction effects on soil moisture determined at the different crop growth stages in northern Ethiopia (2013 cropping season).

\begin{tabular}{lccccc}
\hline Source & DF & SS & MS & $F$ & $P$ \\
\hline \multicolumn{4}{l}{ ANOVA of soil moisture determined at sowing time with } & response \\
to fertilizer, variety, & and their & interaction \\
Replication & 2 & 2.000 & 1.000 & & \\
Fertilizer (F) & 3 & 14.25 & 4.75 & 10.87 & 0.017 \\
Variety (V) & 2 & 4.056 & 2.028 & 4.642 & $0.09^{\text {ns }}$ \\
F $\times$ V & 6 & 3.222 & 0.537 & 1.229 & $0.2782^{\text {ns }}$ \\
Error & 22 & 9.611 & 0.437 & & \\
Total & 35 & 31.139 & & & \\
\hline
\end{tabular}

ANOVA of soil moisture determined at 33 days after sowing with response to fertilizer, variety, and their interaction

\begin{tabular}{lccccc} 
Replication & 2 & 2.000 & 1.000 & & \\
Fertilizer (F) & 3 & 130 & 43.33 & 32.19 & 0.0001 \\
Variety (V) & 2 & 14.39 & 7.195 & 5.35 & $0.0800^{\text {ns }}$ \\
F $\times$ V & 6 & 194.9 & 32.48 & 24.13 & 0.0002 \\
Error & 22 & 29.611 & 1.3460 & & \\
Total & 35 & 368.9 & & & \\
\hline
\end{tabular}

ANOVA of soil moisture determined at 49 days after sowing with response to fertilizer, variety, and their interaction

\begin{tabular}{lccccc} 
Replication & 2 & 2.000 & 1.000 & & \\
Fertilizer (F) & 3 & 262.3 & 87.4 & 36.79 & 0.0001 \\
Variety (V) & 2 & 89.56 & 44.78 & 18.84 & 0.0010 \\
F $\times$ V & 6 & 197.0 & 32.83 & 13.82 & 0.0030 \\
Error & 22 & 52.28 & 2.376 & & \\
Total & 35 & 601.1 & & & \\
\hline
\end{tabular}

ANOVA of soil moisture determined at 64 days after sowing with response to fertilizer, variety, and their interaction

$\begin{array}{lccccc}\text { Replication } & 2 & 2.000 & 1.000 & & \\ \text { Fertilizer (F) } & 3 & 207 & 69 & 27.97 & 0.0001 \\ \text { Variety (V) } & 2 & 62.167 & 31.08 & 12.60 & 0.004 \\ \text { F } \times \text { V } & 6 & 164.2 & 27.37 & 11.09 & 0.0042 \\ \text { Error } & 22 & 54.278 & 2.467 & & \\ \text { Total } & 35 & 487.64 & & & \end{array}$

ANOVA of soil moisture determined at 84 days after sowing with response to fertilizer, variety, and their interaction

$\begin{array}{lccccc}\text { Replication } & 2 & 2.000 & 1.000 & & \\ \text { Fertilizer (F) } & 3 & 152 & 50.67 & 29.4628147 & 0.0001 \\ \text { Variety (V) } & 2 & 24.22 & 12.111 & 7.04258187 & 0.0301 \\ \text { F } \times \text { V } & 6 & 205 & 34.17 & 19.8680165 & 0.0001 \\ \text { Error } & 22 & 37.833 & 1.720 & & \\ \text { Total } & 35 & 419.05 & & & \end{array}$

ANOVA of soil moisture determined at 120 days after sowing with response to fertilizer, variety, and their interaction

\begin{tabular}{lccccc} 
Replication & 2 & $2.051 \mathrm{E}-29$ & $1.026 \mathrm{E}-29$ & & \\
Fertilizer (F) & 3 & 86.25 & 28.75 & 26.79 & 0.0002 \\
Variety (V) & 2 & 18.056 & 9.028 & 8.412 & 0.0010 \\
F $\times$ V & 6 & 153.9 & 25.65 & 23.900 & 0.0002 \\
Error & 22 & 23.611 & 1.073 & & \\
Total & 35 & 281.8 & & & \\
\hline
\end{tabular}

$\mathrm{DF}=$ degree of freedom; $\mathrm{SS}=$ sum of squares; $\mathrm{MS}=$ mean squares: $F=$ calculated value (test statistic); $P=$ probability level; $n s=$ nonsignificant at $P>0.05$.

different growth stages due to the variety Keyih (V3) and Kuncho (V2), respectively, in both cropping seasons (Figure 4(b)). Generally, there were significant differences in SMC response to crop varieties among the different growth stages that is determined at 49,64,84, and 120 DAS in 2012 


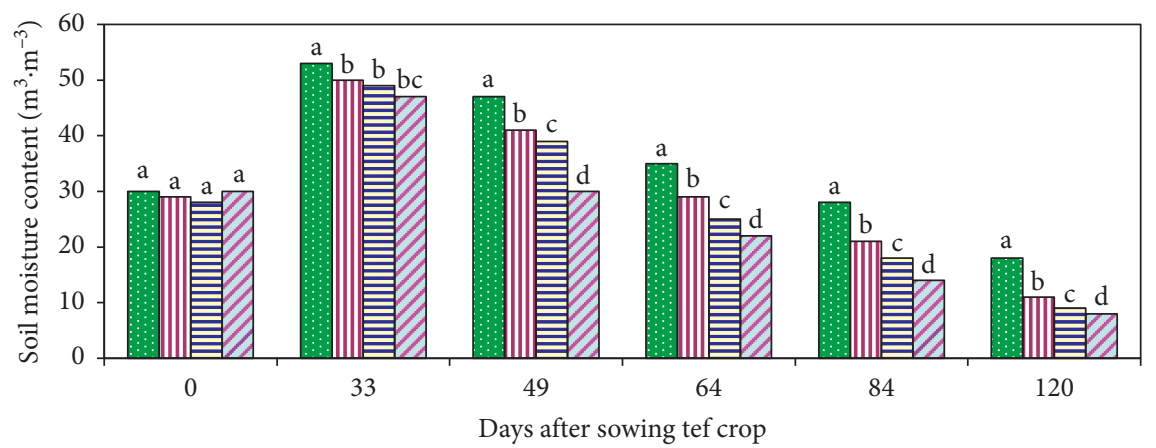

$\mathrm{F}(\mathrm{N}+\mathrm{P})$

a $0+0$

पा $21+10$

घ $41+20$

ㅁ $64+25$

(a)

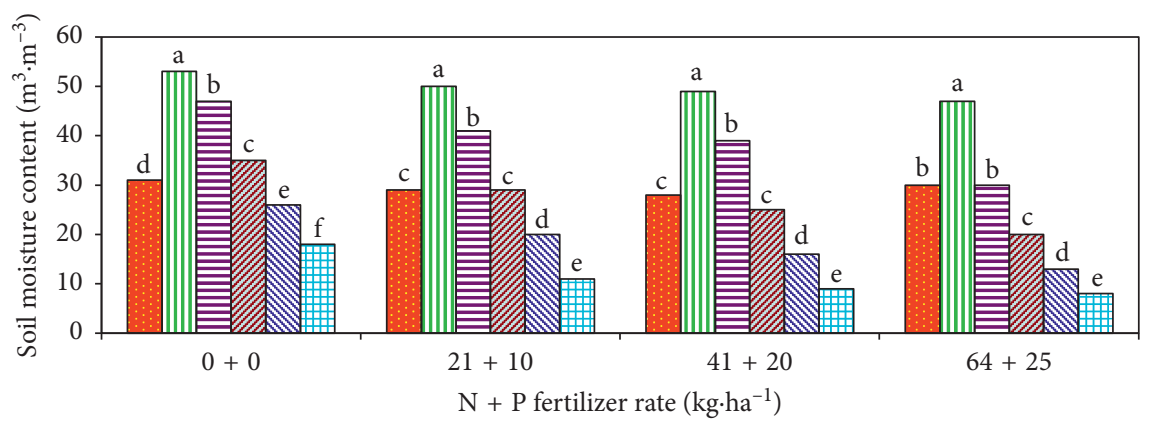

DAS

- 0

๑ 33

(․ 64

ㅂ 49

v 84

口 120

(b)

FIgURE 2: Soil moisture content in the 2012 cropping season affected by (a) fertilizer rates in a given soil sampling date and (b) growth stages (soil sampling dates) for the same fertilizer rate. Note: $\mathrm{F}(\mathrm{N}+\mathrm{P})$ denotes fertilizer $\mathrm{N}$ plus $\mathrm{P}\left(\mathrm{kg}^{\mathrm{h}} \mathrm{ha}^{-1}\right)$ as $0 \mathrm{~N}+0 \mathrm{P}(\mathrm{F} 1), 21 \mathrm{~N}+10 \mathrm{P}(\mathrm{F} 2), 41 \mathrm{~N}+20 \mathrm{P}(\mathrm{F} 3)$, and $64 \mathrm{~N}+25 \mathrm{P}$ (F4); DAS, days after sowing, refers to the soil sampling date to determine SMC.

and 2013 years. However, there were nonsignificant differences in SMC response to the tef varieties determined at 0 DAS and 33 DAS in both 2012 and 2013 cropping seasons. The reason for the nonsignificant difference in SMC determined at these two sampling times with respect to varieties could be associated with the fact that moisture is not a limiting factor for the crop growth. This research thus generalized that soil sampling dates could influence SMC even for the plots treated with the same fertilizer rate (Figures 2(b), 3(b), and 4(a)) and crop varieties (Figure 4(b)), within and across the two cropping seasons.

In agreement to the present results, previous researchers (e.g., $[18,19])$ using long-term fertilizer trials have reported that soil water demand of crops varied with growth stages, and crop water demand decreased towards the end of the growing season. In addition, consistent with the present finding that soil moisture decreases when fertilizer rate increases, reports from elsewhere have shown that adequate nutrient supply can contribute to increasing water and nutrient uptake (more water used) by plants from the soil, thereby decreasing available soil moisture for producing better crop growth $[20,21]$. Previous reports have also stated that available soil moisture could be reduced by long-term $\mathrm{N}$ and $\mathrm{P}$ fertilization as this considerably increases crop water use for transpiration which resulted in a decrease in soil moisture within a soil profile [19, 22-24]. However, such reports have not evaluated SMC from the context of the short-term effects of fertilization on crop varieties in which this was addressed by the present research.

In the present research, the trends of SMC indicate that the highest SMC was found from plots treated with no fertilizer. The implication is that when fertilizer rates increased, there is high soil water depletion by the plant for being nutrients available regardless of the type of variety $[18,19,22-24]$. Other researchers have reported that the successive use of chemical fertilizers leads to the deterioration of soil quality due to effects on nutrient imbalances $[25,26]$.

3.2. Average Soil Moisture Content of 2012 and 2013 Cropping Seasons. The average soil moisture contents (ASMC) determined at the different soil sampling dates with respect to the fertilizer rates from both cropping seasons (2012 and 2013) are shown in Figures 5(a) and 5(b). The ASMC 


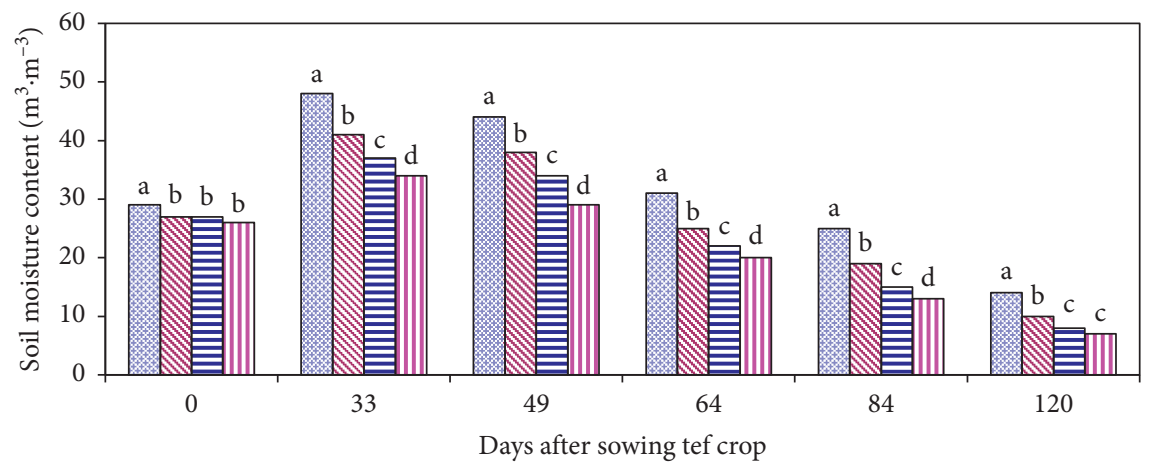
$\mathrm{F}(\mathrm{N}+\mathrm{P})$
圆 $0+0$
回 $21+10$
$41+20$
$\square 64+25$

(a)

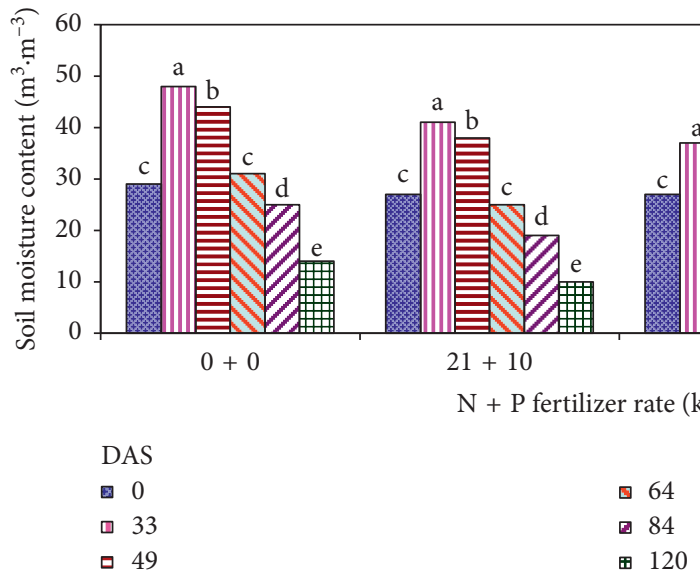

(b)

Figure 3: Soil moisture content in the 2013 cropping season as affected by (a) fertilizer rates in a given sampling date and (b) growth stages (sampling dates) for the same fertilizer rate. Note: $\mathrm{F}(\mathrm{N}+\mathrm{P})$ denotes fertilizer $\mathrm{N}$ plus $\mathrm{P}\left(\mathrm{kg}^{\mathrm{h}} \mathrm{ha}^{-1}\right)$ as $0 \mathrm{~N}+0 \mathrm{P}(\mathrm{F} 1), 21 \mathrm{~N}+10 \mathrm{P}(\mathrm{F} 2), 41 \mathrm{~N}+20$ $\mathrm{P}$ (F3), and $64 \mathrm{~N}+25 \mathrm{P}$ (F4); DAS, days after sowing, refers to the soil sampling date to determine SMC.

determined at 0 DAS showed significant differences between the plots that received $\mathrm{F} 1$ and the remaining fertilizer rates (F2, F3, and F4). Statistically significant differences in ASMC among the fertilizer rates were also observed during the sampling dates of 33, 49, 64, and 84 DAS. ASMC determined at 120 DAS showed significant differences between $\mathrm{F} 1$ and the remaining rates and between $\mathrm{F} 2$ and the other fertilizer rates. However, the ASMC determined at 120 DAS did not show significant difference between F3 and F4 (Figure 5(a)).

Furthermore, the ASMC due to F1 showed significant differences across all the soil sampling dates, except the nonsignificant differences between 0 and 64 DAS and 0 and 84 DAS. The ASMC determined from plots that received F2 across all the sampling dates showed significant differences, with the exceptional nonsignificant difference between 0 and 64 DAS. The ASMC determined at the different soil sampling dates from the plots treated with F3 and F4 also showed significant differences. Generally, a significantly higher ASMC was recorded due to F1 followed by F2, while a significantly lower ASMC was found due to F4 followed by F3. The highest ASMC response to the different fertilizer rates was determined at the sampling date of 33 DAS followed by 49 DAS, while the lowest was at 120 DAS followed by 84 DAS (Figure $5(\mathrm{~b})$ ). The soil sampling dates' $\times$ fertilizer rates $\times$ cropping seasons (years) and soil sampling dates' $\times$ varieties $\times$ years in which the three-way interactions did show significant effect on ASMC (data not shown).

3.3. Comparison of SMC Determined from Fertilized Plots with FC and PWP. In 2012 and 2013 cropping seasons, the SMC determined at 33 and 49 DAS of the tef crop growth stages with respect to the effects of the fertilizer rates showed higher moisture than that at field capacity, FC $\left(27 \mathrm{~m}^{3} \cdot \mathrm{m}^{-3}\right)$, and permanent wilting point, $\operatorname{PWP}\left(12 \mathrm{~m}^{3} \cdot \mathrm{m}^{-3}\right)$. The SMC determined at 0 DAS in both cropping seasons also showed almost the same values with that of the FC. In 2012, the SMC determined at $0,33,49$, and 64 DAS from the plots treated with F1 and F2 showed higher than the FC as compared to the plots treated with F3 and F4. The trend of the SMC in the 2012 cropping season was similar to that of 2013, except the moisture at 0 DAS in 2013 which was slightly lower than the FC. In both cropping seasons, the SMC response to F2, F3, 


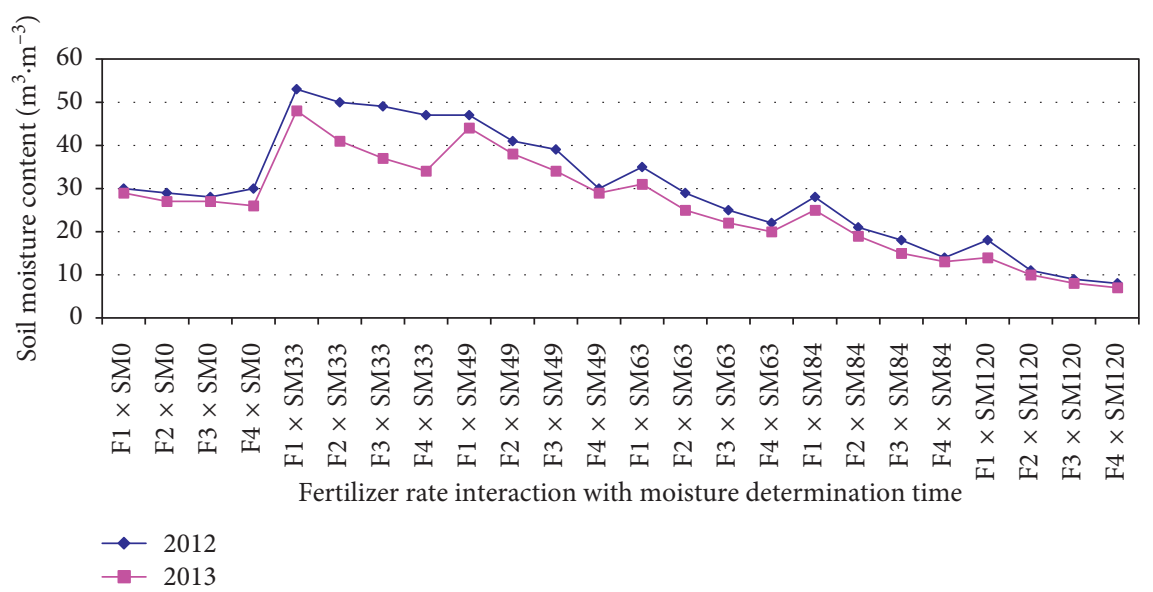

(a)

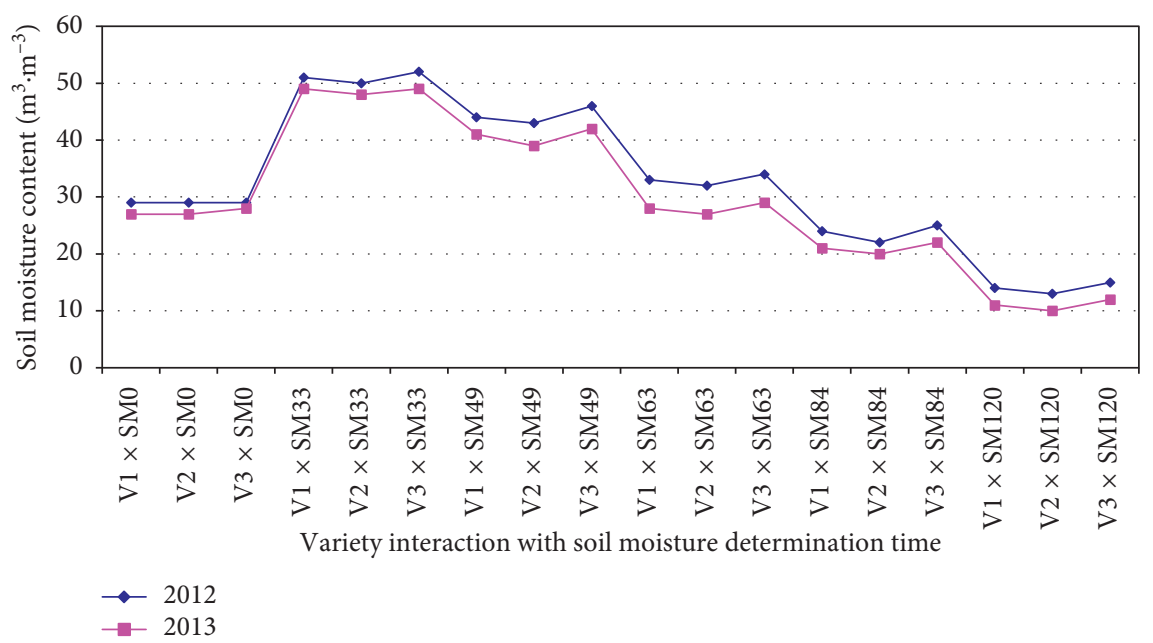

(b)

FIGURE 4: Soil moisture affected by (a) fertilizer rates interacted with SMC determination time (crop growth stage) across years and (b) tef varieties interaction with SMC determination time (crop growth stage) across years. Note: $\mathrm{F}(\mathrm{N}+\mathrm{P})$ denotes fertilizer $\mathrm{N}$ plus $\mathrm{P}\left(\mathrm{kg} \cdot \mathrm{ha}{ }^{-1}\right)$ as 0 $\mathrm{N}+0 \mathrm{P}(\mathrm{F} 1), 21 \mathrm{~N}+10 \mathrm{P}(\mathrm{F} 2), 41 \mathrm{~N}+20 \mathrm{P}$ (F3), and $64 \mathrm{~N}+25 \mathrm{P}$ (F4); SM refers to soil moisture determined at 0, 33, 49, 64, 84, and 120 days after sowing (DAS).

and F4 at 120 DAS was lower than the PWP, but the lowest was to F4 (Figures 2(b) and 3(b)). Similarly, in both cropping seasons, the SMC determined at 64 DAS due to F1 followed by F2 indicated to be higher than that of the FC. The SMC at 64 DAS due to F3 followed by F4 plots showed slightly lower values than that of the FC. The SMC determined at 84 DAS was lower than that of the FC across all the fertilized plots except the plots treated with F1. The SMC determined at 120 DAS was extremely lower than that of the FC across all the experimental plots treated with fertilizer. In addition, the average SMC determined at 0,33, 49, 64, and 84 DAS from all the plots treated with the fertilizer rates (F1 to F4) was higher than that of the PWP. However, SMC determined at 84 DAS was found to be slightly higher than that of the PWP with fertilization. Such results indicate that SMC is enough (higher than PWP) for the tef crop varieties along most of the crop growth stages (from planting up to the booting stage) for all fertilizer treatments, but the crop variety V2 suffered due to moisture shortage starting at the grain filling stage (84 DAS) due to F4. As a result, V3 is suggested to practice with fertilizer and without fertilizer in moisture stressed areas such as the trial site in Ethiopia.

Generally, with respect to the separate effects of the different tef varieties, SMC determined at $0,33,49$, and 64 DAS showed higher FC. A higher SMC than the FC was observed due to V3 followed by V1. This indicates that improved variety (V2) seems to be much water demanding than the local ones. Except V3 with slightly higher SMC than the PWP at 120 DAS, the average SMC of the two years with respect to the other tef varieties showed lower values than the PWP. The implication is SMC determined during the soil sampling dates that showed lower PWP could be associated with the high plant water demand and/or moisture lost due to evaporation. Such loss of SMC might be the cause to decrease the crop yield as the rate of fertilizer increases, but these merits further help to quantify the magnitude of yield being lost with respect to each of the treatments in the study area condition. 


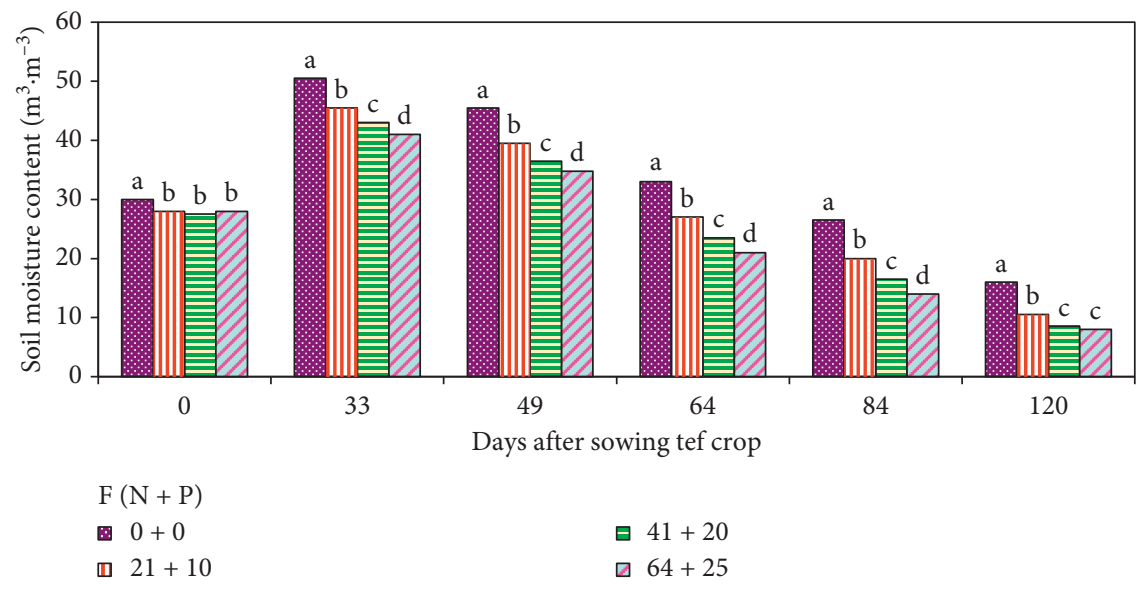

(a)

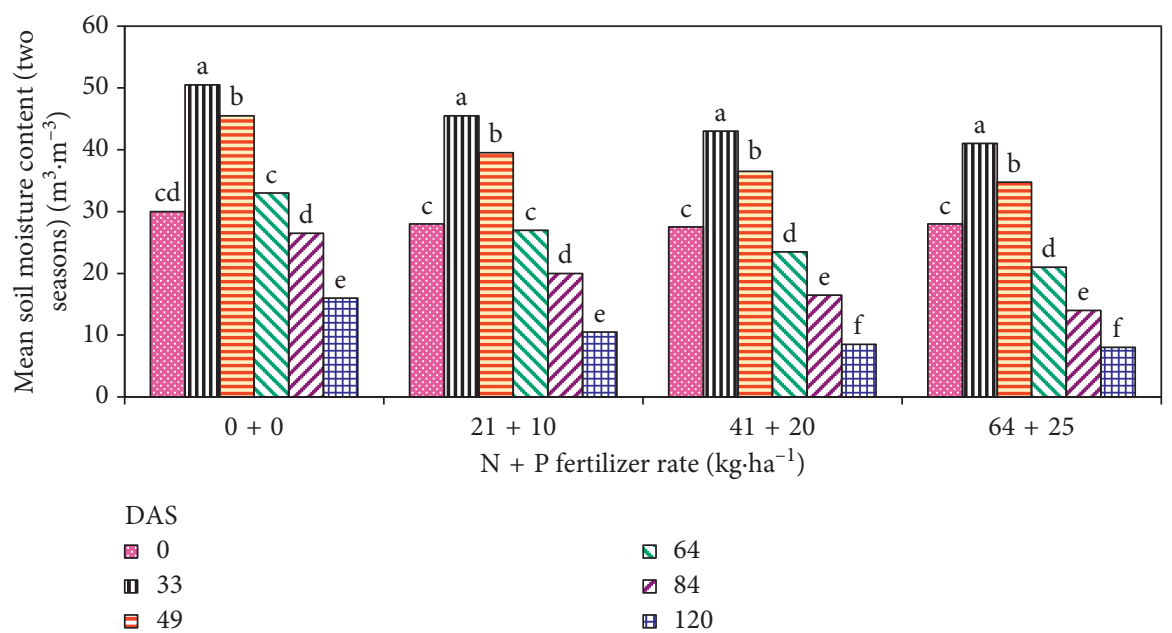

(b)

Figure 5: Average soil moisture content of 2012 and 2013 as affected by (a) fertilizer rates in a given sampling date and (b) growth stages (sampling dates) for the same fertilizer rate. Note: F ( N + P) denotes fertilizer N plus P $\left(\mathrm{kg}^{\circ} \mathrm{ha}^{-1}\right)$ as $0 \mathrm{~N}+0 \mathrm{P}(\mathrm{F} 1), 21 \mathrm{~N}+10 \mathrm{P}(\mathrm{F} 2), 41 \mathrm{~N}+20$ $\mathrm{P}(\mathrm{F} 3)$, and $64 \mathrm{~N}+25 \mathrm{P}(\mathrm{F} 4)$; DAS, days after sowing, refers to the soil sampling date to determine SMC.

3.4. Combined Treatment Effects on Soil Moisture Content under the Tef Cropping System. The results of the combined effects of the fertilizer rates with tef varieties on SMC showed significant differences within and among most of the soil sampling dates $(33,49,64,84$, and 120 DAS) in the 2012 crop season (Tables 2 and 4). The SMC determined from F1V3 treatment was significantly higher than the other treatment combinations across all the sampling dates. The lowest SMC was observed due to F4V2 from the treatment combinations at all the sampling dates (Table 4). However, there was a nonsignificant difference in the SMC determined at 0 DAS among the treatment combinations. This could be associated with the reason that the soil samples were collected just at sowing time, i.e., before the treatments imposed in 2012. There was also nonsignificant differences in the SMC determined at 33 DAS among some treatment combinations (e.g., between F1V1 and F2V3, F2V1 and F3V3, F3V1 and F4V3, and F3V2 and F4V1). Similarly, the SMC determined at the remaining sampling dates showed nonsignificant differences among some of the treatment combinations (Table 4).
The average SMC determined at all the sampling dates in 2012 showed significant variability among most of the treatment combinations. The average SMC determined from treatment combination (e.g., F1V1) within and across the soil sampling dates also indicated significant variability (Table 4). The SMC due to the treatment combinations indicated that SMC increased up to the 33 DAS and then decreased at 49 DAS which showed a similar trend with the separate effects of the fertilizer rate and crop variety in the 2012 cropping season.

In addition, there were significant differences in SMC determined at each of the soil sampling dates due to the treatment combination effects in the 2013 cropping season (Tables 3 and 5). The treatment combinations of F1 with the tef varieties showed significantly higher SMC at the different growth stages as compared to the other treatment combinations in 2013. For example, the highest SMC was recorded from F1V3 followed by F1V1, whereas the lowest was found from F4V2. Such trend showed that the SMC decreased when the fertilizer rate application increased with V2 than 
TABle 4: Combined effects of $\mathrm{N}+\mathrm{P}$ fertilizer rates with tef crop varieties on soil moisture content (SMC) determined at the different growth stages (sampling dates) in the 2012 cropping season in the Dura area, northern Ethiopia.

\begin{tabular}{|c|c|c|c|c|c|c|c|c|}
\hline \multirow{2}{*}{ Treatment } & \multicolumn{6}{|c|}{ SMC by sampling date (days after sowing time, DAS) } & \multirow{2}{*}{ Average $^{\#}$} & \multirow{2}{*}{ Significance } \\
\hline & 0 DAS & 33 DAS & 49 DAS & 64 DAS & 84 DAS & 120 DAS & & \\
\hline F1V1 & $30 \mathrm{a}$ & $53 \mathrm{~b}$ & $44 \mathrm{bc}$ & $35 \mathrm{~b}$ & $25 \mathrm{bc}$ & $15 \mathrm{c}$ & $34 \mathrm{~b}$ & $* *$ \\
\hline F1V2 & $29 \mathrm{a}$ & $50 \mathrm{~d}$ & $39 \mathrm{f}$ & $30 \mathrm{e}$ & $21 \mathrm{de}$ & $13 \mathrm{~cd}$ & $31 \mathrm{~cd}$ & $* *$ \\
\hline F1V3 & $29 \mathrm{a}$ & $55 \mathrm{a}$ & $47 \mathrm{a}$ & $39 \mathrm{a}$ & $29 \mathrm{a}$ & $18 \mathrm{a}$ & $37 \mathrm{a}$ & ** \\
\hline $\mathrm{F} 2 \mathrm{~V} 1$ & $30 \mathrm{a}$ & $51 \mathrm{~cd}$ & $42 \mathrm{~cd}$ & $32 \mathrm{~d}$ & $22 \mathrm{~cd}$ & $13 \mathrm{de}$ & $32 \mathrm{bc}$ & $* *$ \\
\hline $\mathrm{F} 2 \mathrm{~V} 2$ & $30 \mathrm{a}$ & $48 \mathrm{e}$ & $37 \mathrm{~g}$ & $27 \mathrm{f}$ & $19 \mathrm{f}$ & $11 \mathrm{fg}$ & $29 \mathrm{e}$ & $* *$ \\
\hline $\mathrm{F} 2 \mathrm{~V} 3$ & $30 \mathrm{a}$ & $53 \mathrm{~b}$ & $44 \mathrm{~b}$ & $35 \mathrm{~b}$ & $26 \mathrm{~b}$ & $16 \mathrm{bc}$ & $34 \mathrm{~b}$ & $* *$ \\
\hline F3V1 & $29 \mathrm{a}$ & $48 \mathrm{de}$ & $40 \mathrm{ef}$ & $30 \mathrm{e}$ & 20 ef & $10 \mathrm{~g}$ & $30 \mathrm{de}$ & $* *$ \\
\hline F3V2 & $30 \mathrm{a}$ & $45 \mathrm{f}$ & $35 \mathrm{~h}$ & $25 \mathrm{~g}$ & $17 \mathrm{~g}$ & $7 \mathrm{ij}$ & $27 \mathrm{f}$ & $*$ \\
\hline F3V3 & $30 \mathrm{a}$ & $51 \mathrm{~cd}$ & $43 c$ & $33 \mathrm{~cd}$ & $24 \mathrm{c}$ & $12 \mathrm{ef}$ & $32 \mathrm{bc}$ & $* *$ \\
\hline $\mathrm{F} 4 \mathrm{~V} 1$ & $29 \mathrm{a}$ & $45 \mathrm{f}$ & $37 \mathrm{~g}$ & $27 \mathrm{f}$ & $17 \mathrm{~g}$ & 8 hi & $27 \mathrm{f}$ & $*$ \\
\hline $\mathrm{F} 4 \mathrm{~V} 2$ & $29 \mathrm{a}$ & $42 \mathrm{~g}$ & $33 \mathrm{i}$ & $22 \mathrm{~h}$ & $14 \mathrm{~h}$ & $6 j$ & $24 \mathrm{~g}$ & $*$ \\
\hline F4V3 & $29 \mathrm{a}$ & $48 \mathrm{e}$ & $40 \mathrm{ef}$ & $30 \mathrm{e}$ & $20 \mathrm{ef}$ & $10 \mathrm{~g}$ & $30 \mathrm{de}$ & $* *$ \\
\hline
\end{tabular}

Values within a column with different letters are significantly different at the probability level $(P) \leq 0.05$. ${ }^{* *}$ Significant at $P=0.01$; ${ }^{*}$ significant at $P=0.05$. "Mean of all sampling dates for each of the treatment combined effects. "Significant level tested for the combined effects on SMC determined across the sampling dates. F, fertilizer rate: F1, $0 \mathrm{~N}+0$ P; F2, $21 \mathrm{~N}+10$ P; F3, 41 N + 20 P; F4, 64 N + 25 P; V, tef varieties: V1, Sergen; V2, DZ-cr-387 or Kuncho; V3, Keyih; $\mathrm{FV}$, interaction (combined) effects of fertilizer with variety.

TABLE 5: Combined effects of $\mathrm{N}+\mathrm{P}$ fertilizer rates with tef crop varieties on soil moisture content (SMC) determined at the different growth stages (sampling dates) in the 2013 cropping season in the Dura area, northern Ethiopia.

\begin{tabular}{|c|c|c|c|c|c|c|c|c|}
\hline \multirow{2}{*}{ Treatment } & \multicolumn{6}{|c|}{ SMC by sampling date (days after sowing, DAS) } & \multirow{2}{*}{ Average $^{\#}$} & \multirow{2}{*}{ Significance } \\
\hline & 0 DAS & 33 DAS & 49 DAS & 64 DAS & 84 DAS & 120 DAS & & \\
\hline F1V1 & $28.0 \mathrm{a}$ & $49 \mathrm{~b}$ & $40 \mathrm{~cd}$ & $31 \mathrm{~b}$ & $21 \mathrm{~cd}$ & $13 \mathrm{c}$ & $30 \mathrm{~cd}$ & ** \\
\hline F1V2 & $28.0 \mathrm{a}$ & $46 \mathrm{~cd}$ & $35 \mathrm{~g}$ & $26 \mathrm{de}$ & 17 ef & $11 \mathrm{~d}$ & $27 \mathrm{de}$ & $* *$ \\
\hline F1V3 & $28.7 \mathrm{a}$ & $52 \mathrm{a}$ & $43 \mathrm{ab}$ & $35 \mathrm{a}$ & $25 \mathrm{a}$ & $16 \mathrm{a}$ & $33 \mathrm{a}$ & $* *$ \\
\hline $\mathrm{F} 2 \mathrm{~V} 1$ & $27.0 \mathrm{~b}$ & $47 \mathrm{c}$ & $38 \mathrm{e}$ & $28 \mathrm{c}$ & $18 \mathrm{de}$ & $11 \mathrm{de}$ & $29 \mathrm{~d}$ & $* *$ \\
\hline $\mathrm{F} 2 \mathrm{~V} 2$ & $26.7 \mathrm{~b}$ & $44 \mathrm{e}$ & $33 \mathrm{~h}$ & $23 \mathrm{e}$ & $15 \mathrm{gh}$ & $9 \mathrm{fg}$ & $25 \mathrm{fg}$ & $* *$ \\
\hline $\mathrm{F} 2 \mathrm{~V} 3$ & $27.3 \mathrm{~b}$ & $49 \mathrm{~b}$ & $42 \mathrm{~b}$ & $31 \mathrm{~b}$ & $22 \mathrm{~b}$ & $14 \mathrm{bc}$ & $31 \mathrm{bc}$ & $* *$ \\
\hline F3V1 & $26.0 \mathrm{c}$ & $44 \mathrm{e}$ & $36 \mathrm{fg}$ & $26 \mathrm{~d}$ & $16 \mathrm{f}$ & $8 \mathrm{~g}$ & 26 ef & $* *$ \\
\hline F3V2 & $25.7 \mathrm{c}$ & $41 \mathrm{f}$ & $31 \mathrm{i}$ & $21 \mathrm{f}$ & $13 \mathrm{i}$ & $5 \mathrm{ij}$ & $23 \mathrm{~h}$ & $*$ \\
\hline F3V3 & $26.7 \mathrm{~b}$ & $47 \mathrm{c}$ & $39 \mathrm{de}$ & $29 \mathrm{bc}$ & $20 \mathrm{c}$ & $10 \mathrm{ef}$ & $29 \mathrm{~d}$ & $* *$ \\
\hline $\mathrm{F} 4 \mathrm{~V} 1$ & $25.3 \mathrm{~cd}$ & $41 \mathrm{f}$ & $33 \mathrm{~h}$ & $23 \mathrm{e}$ & $13 \mathrm{i}$ & $6 \mathrm{hi}$ & $24 \mathrm{gh}$ & $*$ \\
\hline F4V2 & $25.0 \mathrm{~d}$ & $38 \mathrm{~g}$ & $29 \mathrm{j}$ & $18 \mathrm{~g}$ & $10 \mathrm{j}$ & $4 \mathrm{i}$ & $21 \mathrm{i}$ & $*$ \\
\hline F4V3 & $25.7 c$ & $44 \mathrm{e}$ & $36 \mathrm{fg}$ & $26 \mathrm{~d}$ & $16 \mathrm{fg}$ & $8 \mathrm{~g}$ & $26 \mathrm{ef}$ & $* *$ \\
\hline
\end{tabular}

Values within a column with different letters are significantly different at the probability level $(P) \leq 0.05$. ${ }^{* *}$ Significant at $P=0.01 ;{ }^{*}$ significant at $P=0.05$. ${ }^{*}$ Mean of all sampling dates for each of the treatment combined effects. "Significant level tested for the treatment combined effects on SMC determined across the sampling dates. F, fertilizer rate: F1, $0 \mathrm{~N}+0$ P; F2, $21 \mathrm{~N}+10$ P; F3, $41 \mathrm{~N}+20$ P; F4, 64 N + 25 P; V, tef varieties: V1, Sergen; V2, DZ-cr-387 or Kuncho; V3, Keyih; FV, interaction (combined) effect of fertilizer with variety.

the other two varieties. The implication is that V2 is more responsive to fertilizer application and thereby to moisture depletion than the other local varieties tested. The highest SMC due to the treatment combinations was determined at the 33 DAS followed by 49 DAS in the 2013 crop season, and moisture has started to decrease from this time of the tef crop growth stage (Table 5).

The average SMC of all the treatment combinations determined at each of the sampling date showed significant variability in 2013. The average SMC determined from a given treatment combination (e.g., F1V1) across all the soil sampling dates also varied significantly from each other (Table 5). The average SMC determined from the treatment combinations increased up to the 33 DAS and then started to decrease at 49 DAS which showed a similar trend with that of 2012 and 2013 cropping seasons and that of the separate effects of fertilizer and crop varieties on SMC in the different growth stages across the years.
The analysis result of the average soil moisture content (ASMC) of 2012 and 2013 determined at each soil sampling date showed significant differences among most treatment combinations (Table 6). The ASMC of all sampling dates determined from each treatment combinations of both years also indicated significant variability, with the highest being due to F1V3 and the lowest being due to F4V2. Similarly, the ASMC determined at the different soil sampling dates due to the treatment combinations (interactions) showed significant variability, while the highest was observed during the sampling date at 33 DAS and the lowest was at 120 DAS (Table 6). However, there were nonsignificant differences in ASMC among some of the treatment combinations determined at the different sampling dates (Table 6). Generally, the trend of SMC due to fertilizer and variety interaction effects across the growth stages and years was similar to the separate effects of fertilizer and variety. 
TABLE 6: Average soil moisture content (SMC) response to the combined effects of $\mathrm{N}+\mathrm{P}$ fertilizer rates with tef crop varieties using the 2012 and 2013 cropping seasons in the Dura area, northern Ethiopia.

\begin{tabular}{|c|c|c|c|c|c|c|c|c|}
\hline \multirow{2}{*}{ Treatment } & \multicolumn{6}{|c|}{ SMC by sampling time (days after sowing, DAS) } & \multirow{2}{*}{ Average $^{\#}$} & \multirow{2}{*}{ Significance $^{\mathrm{b} q}$} \\
\hline & 0 & 33 & 49 & 64 & 84 & 120 & & \\
\hline F1V1 & $29.0 \mathrm{ab}$ & $51 \mathrm{~b}$ & $42 \mathrm{~cd}$ & $33 \mathrm{~b}$ & $23 \mathrm{~cd}$ & $14 \mathrm{c}$ & $31 \mathrm{c}$ & ** \\
\hline F1V2 & $28.5 \mathrm{~b}$ & $48 \mathrm{c}$ & $37 \mathrm{f}$ & $28 \mathrm{e}$ & $19 \mathrm{fg}$ & $12 \mathrm{de}$ & $28 \mathrm{f}$ & $* *$ \\
\hline F1V3 & $28.9 \mathrm{ab}$ & $53 \mathrm{a}$ & $45 \mathrm{ab}$ & $37 \mathrm{a}$ & $27 \mathrm{a}$ & $17 \mathrm{a}$ & $34 \mathrm{a}$ & $* *$ \\
\hline $\mathrm{F} 2 \mathrm{~V} 1$ & $28.5 \mathrm{~b}$ & $49 \mathrm{~cd}$ & $40 \mathrm{e}$ & $30 \mathrm{~d}$ & 20 ef & $12 \mathrm{~d}$ & $29 \mathrm{e}$ & $* *$ \\
\hline F2V2 & $28.4 \mathrm{~b}$ & $46 \mathrm{~d}$ & $35 \mathrm{~g}$ & $25 \mathrm{f}$ & $17 \mathrm{~h}$ & $10 \mathrm{fg}$ & $26 \mathrm{~h}$ & $* *$ \\
\hline $\mathrm{F} 2 \mathrm{~V} 3$ & $28.7 \mathrm{~b}$ & $51 \mathrm{~b}$ & $44 \mathrm{~b}$ & $33 \mathrm{~b}$ & $24 \mathrm{bc}$ & $15 \mathrm{~b}$ & $32 \mathrm{~b}$ & $* *$ \\
\hline F3V1 & $27.5 \mathrm{~d}$ & $46 \mathrm{~d}$ & 38 ef & $28 \mathrm{e}$ & $18 \mathrm{gh}$ & $9 \mathrm{~g}$ & $27 \mathrm{~g}$ & $* *$ \\
\hline F3V2 & $27.9 \mathrm{~cd}$ & $43 \mathrm{f}$ & $33 \mathrm{i}$ & $23 \mathrm{~g}$ & $15 \mathrm{~g}$ & $6 \mathrm{ij}$ & $24 \mathrm{j}$ & * \\
\hline F3V3 & $28.4 \mathrm{~b}$ & $49 \mathrm{~cd}$ & $41 \mathrm{~d}$ & $31 \mathrm{c}$ & $22 \mathrm{~d}$ & $11 \mathrm{ef}$ & $30 \mathrm{~d}$ & $* *$ \\
\hline F4V1 & $27.2 \mathrm{de}$ & $43 \mathrm{e}$ & $35 \mathrm{~g}$ & $25 \mathrm{f}$ & $15 \mathrm{i}$ & 7 hi & $25 \mathrm{i}$ & $*$ \\
\hline $\mathrm{F} 4 \mathrm{~V} 2$ & $27.0 \mathrm{de}$ & $40 \mathrm{f}$ & $31 \mathrm{~h}$ & $20 \mathrm{~h}$ & $12 \mathrm{j}$ & $5 \mathrm{j}$ & $22 \mathrm{k}$ & $*$ \\
\hline F4V3 & $27.4 \mathrm{~d}$ & $46 \mathrm{~d}$ & 38 ef & $28 \mathrm{e}$ & $18 \mathrm{gh}$ & $9 \mathrm{~g}$ & $27 \mathrm{~g}$ & $* *$ \\
\hline
\end{tabular}

Values within a column with different letters are significantly different at the probability level $(P) \leq 0.05$. ${ }^{* *}$ Significant at $P=0.01 ;{ }^{*}$ significant at $P=0.05$. ${ }^{*}$ Mean of all sampling dates for each of the treatment combined effects. "Significant level test for the interaction effects on SMC determined across the sampling dates. F, fertilizer rates: F1, 0 N + 0 P; F2, 21 N + 10 P; F3, 41 N + 20 P; F4, 64 N + 25 P; V, tef varieties: V1, Sergen; V2, DZ-cr-387 or Kuncho; V3, Keyih; FV, interaction (combined) effect of fertilizer with variety.

3.5. Paired Mean Comparison and Correlation of Soil Moisture between 2012 and 2013. The trend of the SMC response to fertilizer, variety, and their interaction determined at the different growth stages (soil sampling date) showed higher in 2012 than the 2013 crop season (Figures 3(a) and 3(b)). Such differences in SMC between crop seasons could be associated with rainfall amount and distribution and variation in water demanded for nutrient mining by the crop. The paired mean differences of the SMC determined due to the treatment effects of the fertilizer rates differed significantly in most of the soil sampling dates between the two cropping seasons (Table 7). Positive values of mean differences in SMC between the cropping seasons indicate that SMC was higher in 2012 on average by $12 \%$ as compared to the 2013 cropping season due to the combined effects of $\mathrm{N}+\mathrm{P}$ fertilizer rates with tef crop varieties (Tables 4 and 5). This finding is consistent with the previous reports (e.g., $[19,23,24])$ who have reported that increasing fertilizer application for consecutive years causes depletion of soil water. There were significant paired mean differences in SMC among most treatments between the same sampling date (growth stage) in the two cropping seasons (Table 7), indicating that the short-term effects of the treatments on SMC across the years are well noticed. The highest mean difference in SMC between 2012 and 2013 crop seasons was found between SM33_F4_12 and SM33_F4_13 $\left(13.0 \mathrm{~m}^{3} \cdot \mathrm{m}^{-3}\right)$ followed by SM33_F3_12 and SM33_F3_13 $\left(12.0 \mathrm{~m}^{3} \cdot \mathrm{m}^{-3}\right)$. Such differences indicated that the SMC in 2013 was decreased by up to $28 \%$ due to continuous fertilization for consecutive two years regardless of the tef crop variety. On the contrary, the lowest paired mean differences in SMC were found between SM120_F3_12 and SM120_F3_13 and SM120_F4_12 and SM120_F4_13. This implies that the successive (2012-2013) application of higher fertilizer rates in the short term could decrease significantly SMC determined even at crop harvesting time. The paired mean differences in SMC due to the interaction effects of fertilizer and varieties between 2012 and 2013 showed significant differences among many of the treatments. However, the paired mean differences due to the separate effects of tef varieties between the two cropping seasons (2012 and 2013) at the different growth stages showed the trend of decreasing in SMC in which the decrement in moisture was higher on plots treated with the improved variety (V2) than the local varieties (Figure 6).

Paired mean difference comparison and correlation analyses of SMC among the average of all fertilizer rates and tef varieties combined effects at the same sampling date between 2012 and 2013 are shown in Table 8. The positive values of average SMC due to the interaction treatment effects showed that SMC was higher in 2012 than in 2013. The highest overall paired mean difference due to the combined effects of fertilizer and varieties on SMC determined at the same growth stage was found as $2.972 \mathrm{~m}^{3} \cdot \mathrm{m}^{-3}$ (between SM33_2012 and SM33_2013), whereas the lowest was between SM0_2012 and SM0_2013 $\left(1.272 \mathrm{~m}^{3} \cdot \mathrm{m}^{-3}\right)$. The paired mean SMC comparison due to the treatment effects as a mean of all sampling dates between 2012 and 2013 showed significant difference and moisture between the two seasons was strongly associated $(r=0.90$, $P \leq 0.001)$. Generally, the correlation results showed a strong and positively significant association in SMC between the same sampling dates in response to the main and combined treatment effects between the two years (Table 8). Such results show that SMC decreases as fertilizer rates increase in both cropping years, but the extent varied depending on the type of crop variety as there could be variability in their moisture demand and utilization. In support of this, for example, the mean of SMC determined from plots treated with V3 was found to be higher than V2 (Figure 6).

The results of the paired mean comparison indicated that the average SMC determined at the sampling dates with respect to F1, F2, F3, and F4 in 2012 showed significantly higher than that of 2013 cropping season by $9,11,16$, and $17 \%$, respectively. This could be attributed to the rainfall distribution which was somehow better seasonal distribution in 2012 than in 2013. The gradual development of soil 
TABLE 7: Paired-samples $T$-test results of the separate effects of fertilizer rates on soil moisture determined at same sampling times under tef crops between 2012 and 2013 in northern Ethiopia.

\begin{tabular}{|c|c|c|c|c|c|}
\hline \multirow{2}{*}{ Paired soil moisture (SM) } & \multicolumn{2}{|c|}{ Paired difference } & \multirow{2}{*}{ Paired soil moisture (SM) } & \multicolumn{2}{|c|}{ Paired difference } \\
\hline & Mean $^{\#}$ & Significance & & Mean $^{\#}$ & Significance \\
\hline SM0_F1_12 and SM0_F1_13 & 2.00 & $0.184^{\mathrm{ns}}$ & SM64_F1_12 and S64_F1_13 & 3.67 & $0.008^{* *}$ \\
\hline SM0_F2_12 and SM0_F2_13 & 2.00 & $0.225^{\mathrm{ns}}$ & SM64_F2_12 and SM64_F2_13 & 4.33 & $0.006^{* *}$ \\
\hline SM0_F3_12 and SM0_F3_13 & 1.33 & $0.510^{*}$ & SM64_F3_12 and SM64_F3_13 & 3.00 & $0.035^{*}$ \\
\hline SM0_F4_12 and SM0_F4_13 & 3.67 & $0.008^{* *}$ & SM64_F4_12 and SM64_F4_13 & 2.00 & $0.042^{*}$ \\
\hline SM33_F1_12 and SM33_F1_13 & 5.00 & $0.049^{*}$ & SM84_F1_12 and SM84_F1_13 & 3.33 & $0.01^{* *}$ \\
\hline SM33_F2_12 and SM33_F2_13 & 8.33 & $0.006^{* *}$ & SM84_F2_12 and SM84_F2_13 & 2.33 & $0.020^{*}$ \\
\hline SM33_F3_12 and SM33_F3_13 & 12.0 & $0.009^{* *}$ & SM84_F3_12 and SM84_F3_13 & 3.00 & $0.122^{\mathrm{ns}}$ \\
\hline SM33_F4_12 and SM33_F4_13 & 13.0 & $0.008^{* *}$ & SM84_F4_12 and SM84_F4_13 & 1.00 & $0.247^{\mathrm{ns}}$ \\
\hline SM49_F1_12 and SM49_F1_13 & 3.33 & $0.010^{* *}$ & SM120_F1_12 and SM120_F1_13 & 4.00 & $0.074^{\mathrm{ns}}$ \\
\hline SM49_F2_12 and SM49_F2_13 & 3.00 & $0.012^{*}$ & SM120_F2_12 and SM120_F2_13 & 1.33 & $0.057^{\mathrm{ns}}$ \\
\hline SM49_F3_12 and SM49_F3_13 & 4.00 & $0.500^{*}$ & SM120_F3_12 and SM120_F3_13 & 1.00 & $0.478^{\mathrm{ns}}$ \\
\hline SM49_F4_12 and SM49_F4_13 & 1.67 & $0.013^{*}$ & SM120_F4_12 and SM120_F4_13 & 1.00 & $0.478^{\mathrm{ns}}$ \\
\hline
\end{tabular}

${ }^{*}$ Significant at 0.05 probability levels; ${ }^{* *}$ significant 0.01 probability levels $(P)$, respectively; ns, non significant at $P>0.05 . \mathrm{SM}$, soil moisture $\left(\mathrm{m}^{3} \cdot \mathrm{m}^{-3}\right)$ determined at 0, 33, 49, 64, 84, and 120 days after sowing; F1, $0 \mathrm{~N}+0$ P; F2, $21 \mathrm{~N}+10 \mathrm{P} ; \mathrm{F} 3,41 \mathrm{~N}+20$ P; F4, $64 \mathrm{~N}+25 \mathrm{P} ; 12$ and 13, 2012 and 2013 crop season, respectively. SM0_F1_12 refers to soil moisture content at 0 DAS determined from F1-treated plots in the 2012 cropping season. The other abbreviations in Table 7 should be described in a similar way. ${ }^{*}$ Found from the SMC in 2012 minus SMC in 2013 at the same sampling time.

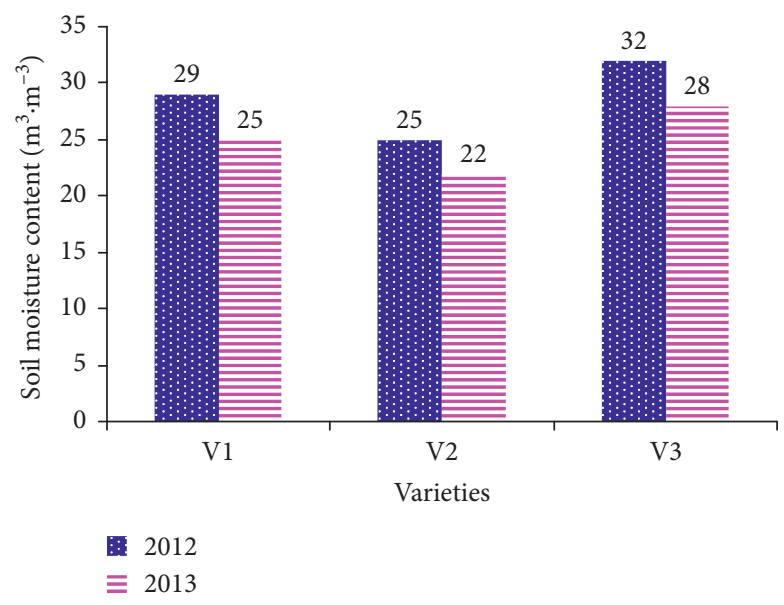

FIgURE 6: Average soil moisture content determined from the different sampling periods in response to the three tef varieties in 2012 and 2013 cropping seasons. Note: for tef varieties: V1, Sergen; V2, DZ-cr-387 or Kuncho; V3, Keyih.

TABLE 8: Paired mean difference comparison and correlation analyses results of soil moisture content response to the average of all fertilizer rates and tef varieties combined effects at the same sampling time between 2012 and 2013 in northern Ethiopia $(n=36)$.

\begin{tabular}{|c|c|c|c|c|c|}
\hline \multirow{2}{*}{ Paired moisture content } & \multicolumn{3}{|c|}{ Paired mean comparison } & \multicolumn{2}{|c|}{ Correlation } \\
\hline & Mean difference & $\mathrm{df}$ & Significance & $r$ & Significance \\
\hline SM0_2012 and SM0_2013 & 1.278 & 35 & $0.040^{*}$ & 0.246 & $0.147^{\text {ns }}$ \\
\hline SM33_2012 and SM33_2013 & 2.972 & 35 & $0.000^{* *}$ & 0.827 & $0.000^{* *}$ \\
\hline SM49_2012 and SM49_2013 & 2.278 & 35 & $0.000^{* *}$ & 0.932 & $0.000^{* *}$ \\
\hline SM64_2012 and SM64_2013 & 2.639 & 35 & $0.000^{* *}$ & 0.921 & $0.000^{* *}$ \\
\hline SM84_2012 and SM84_2013 & 2.639 & 35 & $0.000^{* *}$ & 0.909 & $0.000^{* *}$ \\
\hline SM120_2012 asnd SM120_2013 & 1.306 & 35 & $0.000^{* *}$ & 0.968 & $0.000^{* *}$ \\
\hline${ }^{\#}$ Mean_2012 and Mean_2013 & 2.222 & 35 & $0.001^{* *}$ & 0.904 & $0.000^{* *}$ \\
\hline
\end{tabular}

${ }^{* *}$ Significant at the 0.01 probability level $(P)$; ${ }^{*}$ significant at $P=0.05$; ns, nonsignificant at $P>0.05$; $r$, correlation; SM_2012 and 2013, soil moisture determined at $0,33,49,64,84$, and 120 days after sowing time (DAS) in 2012 and 2013 cropping seasons, respectively. ${ }^{*}$ Overall mean of all sampling dates and the treatment interaction effects on each crop seasons.

compaction due to consecutive usage of the same tillage depth just below and above the plow depth and continuous fertilization-related nutrient imbalance may also result in a soil with low soil moisture content (low infiltration and soil water holding capacity) [11]. In addition, the consecutive application of fertilizer could enhance the use of much soil moisture by the crop in 2013. In line to this, previous researchers (e.g., $[9,12])$ reported that mineral fertilizers (e.g., 
$\mathrm{N}$ and $\mathrm{P}$ fertilizers) do not contribute to improve the soil physical condition such as soil moisture; rather, it deteriorates a soil even though it provides readily available nutrients for plant growth. Such available nutrients need adequate soil moisture to be available for a plant which resulted in deterioration of the soil water profile [19, 22-24].

\section{Conclusions}

This research demonstrated that soil moisture content (SMC) is significantly influenced mainly by the short-term effects of the fertilizer rates and their interactions with tef crop varieties and by the crop growth stages which were used for soil moisture determination in 2012 and 2013 cropping seasons. The highest SMC was observed from F1 $(0 \mathrm{~N}+0$ $\mathrm{P} \mathrm{kg} \cdot \mathrm{ha}^{-1}$ ) treated plots, whereas the lowest was from F4 (64 $\mathrm{N}+25 \mathrm{P} \mathrm{kg} \cdot \mathrm{ha}^{-1}$ ) treated plots across all the soil moisture determination periods and years. This indicates that SMC decreased, while the fertilizer rate increased regardless of the tef variety and growth stages which could be associated with the considerable increase in crop water demand by tef crops for using the available nutrients applied as fertilizer. This study revealed that the SMC determined at the different growth stages (soil moisture determination time) of tef crops from the plots treated with local variety of Keyih (V3) was found to be significantly higher than that of the improved variety of Kuncho (V2) in both cropping seasons. The highest SMC was determined at 33 DAS (days after sowing) across all the plots treated by the separate effects of fertilizer and crop variety and their interactions in both experimental seasons which are associated with the peak amount of rainfall recorded. The highest SMC due to the separate effects of the fertilizer and variety factors and their combined effects at the different growth stages in both cropping seasons was found to be due to F1 and V3 and F1V3, respectively. The lowest SMC due to the separate effects of the fertilizer rates, varieties, and their interaction was reported from F4, V2, and F4V2, respectively. The fertilizer and variety combined effects on SMC showed a slightly lower value than the separate effect of the fertilizer factor, indicating the need for applying the appropriate fertilizer rate. Generally, there is a trend of significant decrement in SMC across the soil sampling dates (tef growth stages) particularly just after 49 DAS due to the separate and interaction treatment effects. Such decrement in SMC was more noticed as a short-term effect of plots treated with a higher rate of fertilizer (e.g., F4) and improved tef variety (V2) and their interactions in both cropping seasons. The overall mean SMC determined at the different growth stages in 2012 was found to be higher by $12 \%$ than that of 2013 . This was also explained by the paired mean differences in SMC at each growth stages due to the fertilizer, variety, and their interactions between the two years which showed higher moisture in 2012 than in 2013. The positive and strong correlation, between the overall SMC determined across the two cropping seasons, indicates that the treatments applied (separate and combined) in the first season (year 1) could influence SMC determined in the next season (year 2) on average by $12 \%$. From the present results, it is generalized that SMC significantly was influenced by the amount of fertilizer applied, type of tef varieties used, and their combined effects, time of soil moisture determination (growth stages), and cropping seasons (years) in the conditions of Chromic Cambisols in northern Ethiopia. Thus, it is suggested to use agronomic practices that improve SMC of the soil profile (e.g., conservation tillage and integration of organic (compost) with inorganic fertilizers) in order to reduce moisture stress related to increasing fertilizer rates in the conditions of the study area.

\section{Data Availability}

The data used to support the findings of this study are included within the article.

\section{Conflicts of Interest}

The author declares that there are no conflicts of interest.

\section{Acknowledgments}

This research was supported by the University of Nebraska, USA, to Aksum University (Ethiopia) under the terms of Grant no. EEP-A-00-06-00016-00 by the U.S. Agency for International Development (USAID) for the Project entitled "Sorghum, Millet, and Other Grains Collaborative Research Support Program" also referred to as INTSORMIL. The author gratefully acknowledges INTSOMIL project for the financial support. The author also appreciates the support of Aksum University during the field work and the development agents of Dura village during trial management and field monitoring.

\section{References}

[1] S. Ketema, "Phenotypic variations in tef (Eragrostis tef) germplasm-morphological and agronomic traits," A Catalon Technical Manual No. 6, Institute of Agricultural Research, Addis Ababa, Ethiopia, 1993.

[2] G. B. Tesfahunegn, "Short-term effects of tillage practices on soil properties under tef [Eragrostis tef (Zucc. Trotter)] crop in Northern Ethiopia," Agricultural Water Management, vol. 148, pp. 241-249, 2015.

[3] CSA (Central Statistical Authority), Agricultural Sample Survey, 2015/2016: Area and Production of Major Crops in Private Peasant Holdings Meher Season, CSA (Central Statistical Authority), Addis Ababa, Ethiopia, 2016.

[4] L. Spaenij-Dekking, Y. Kooy-Winkelaar, and F. Koning, "The Ethiopian cereal tef in celiac disease," New England Journal of Medicine, vol. 353, pp. 16-25, 2005.

[5] W. Shiferaw, A. Balcha, and H. Mohammed, "Genetic variation for grain yield and yield related traits in tef [Eragrostis tef; (Zucc. Trotter)] under moisture stress and non-stress environments," American Journal of Plant Sciences, vol. 3, no. 8, pp. 1041-1046, 2012.

[6] P. J. M. Cooper and P. J. Gregory, "Soil water management in the rain-fed farming system of the Mediterranean region," Soil Use and Management, vol. 3, no. 8, pp. 57-62, 1987.

[7] O. Giday, H. Gibrekidan, and T. Berhe, "Response of teff (Eragrostis tef) to different rates of slow release and conventional urea fertilizers in vertisols of Southern Tigray, 
Ethiopia," Advances in Plants and Agriculture Research, vol. 1, no. $5,2014$.

[8] T. Oicha, W. M. Cornelis, H. Verplancke et al., "Short-term effects of conservation agriculture on vertisols under tef [Eragrostis tef (Zucc. Trotter)] in the Northern Ethiopian highlands," Soil and Tillage Research, vol. 106, no. 2, pp. 294-302, 2010.

[9] A. Singha, T. Adak, K. Kumar, S. K. Shukla, and V. K. Singh, "Effect of integrated nutrient management on dehydrogenase activity, soil organic carbon and soil moisture variability in a mango orchard ecosystem," Journal of Animal and Plant Sciences, vol. 24, pp. 843-849, 2014.

[10] H. Chen, M. Shao, and Y. Li, "The characteristics of soil water cycle and water balance on steep grassland under natural and simulated rainfall conditions in the loess plateau of China," Journal of Hydrology, vol. 360, no. 1-4, pp. 242-251, 2008.

[11] A. Balcha, "Effect of phosphorus rates and varieties on grain yield, nutrient uptake and phosphorus efficiency of tef [Eragrostis tef (Zucc. Trotter)]," American Journal of Plant Sciences, vol. 5, no. 3, pp. 262-267, 2014.

[12] L. Ferreras, E. Gomez, S. Toresani, I. Firpo, and R. Rotondo, "Effect of organic amendments on some physical, chemical and biological properties in a horticultural soil," Bioresource Technology, vol. 97, no. 4, pp. 635-640, 2006.

[13] N. Ziadi, D. A. Angers, B. Gagnon et al., "Long-term tillage and synthetic fertilization affect soil functioning and crop yields in a corn-soybean rotation in eastern Canada," $\mathrm{Ca}$ nadian Journal of Soil Science, vol. 94, no. 3, pp. 365-376, 2014.

[14] G. R. Blake and K. H. Hartge, "Bulk density," in Methods of Soil Analysis, Part 1: Physical and Mineralogical Methods, A. Klute, Ed., pp. 363-375, ASA and SSSA, Madison, WI, USA, 2nd edition, 1986.

[15] J. Landon, A Booker Tropical Soil Manual: a Handbook for Soil Survey and Agricultural Land Evaluation in the Tropics and Subtropics, Booker Tate, Thame, UK, 1991.

[16] D. Hillel, Fundamentals of Soil Physics, Academic Press, London, UK, 1980.

[17] N. C. Brady and R. R. Weil, The Nature and Properties of Soils, Prentice-Hall, Upper Saddle River, NJ, USA, 13th edition, 2002.

[18] W. Zou, B. Si, X. Han, and H. Jiang, "The effect of long-term fertilization on soil water storage and water deficit in the black soil zone in Northeast China," Canadian Journal of Soil Science, vol. 92, no. 3, pp. 439-448, 2012.

[19] B. Wang, W. Liu, Q. Xue et al., "Soil water cycle and crop water use efficiency after long-term nitrogen fertilization in loess plateau," Plant, Soil and Environment, vol. 59, no. 1, pp. 1-7, 2013.

[20] F. Salvagiotti, K. G. Cassman, J. E. Specht, D. T. Walters, A. Weiss, and A. Dobermann, "Nitrogen uptake, fixation and response to fertilizer $\mathrm{N}$ in soybeans: a review," Field Crops Research, vol. 108, no. 1, pp. 1-13, 2008.

[21] T. D. Setiyono, D. T. Walters, K. G. Cassman, C. Witt, and A. Dobermann, "Estimating maize nutrient uptake requirements," Field Crops Research, vol. 118, no. 2, pp. 158$168,2010$.

[22] O. P. Caviglia and V. O. Sadras, "Effect of nitrogen supply on crop conductance, water- and radiation-use efficiency of wheat," Field Crops Research, vol. 69, no. 3, pp. 259-266, 2001.

[23] M. Huang, T. Dang, J. Gallichand, and M. Goulet, "Effect of increased fertilizer applications to wheat crop on soil-water depletion in the Loess Plateau, China," Agricultural Water Management, vol. 58, no. 3, pp. 267-278, 2003.
[24] S. Zhang, X. Yang, M. Wiss, H. Grip, and L. Lövdahl, "Changes in physical properties of a loess soil in China following two long-term fertilization regimes," Geoderma, vol. 136 , no. 3-4, pp. 579-587, 2006.

[25] O. T. Ayoola, "Effects of fertilizer treatments on soil chemical properties and crop yields in a cassava-based cropping system," Journal of Applied Sciences Research, vol. 2, pp. 11121116, 2006.

[26] M. K. Moghadam, H. H. Darvishi, and M. Javaheri, "Evaluation agronomic traits of soybean affected by vermicompost and bacteria in sustainable agricultural system," International Journal of Bioscience, vol. 5, no. 9, pp. 406-413, 2014. 

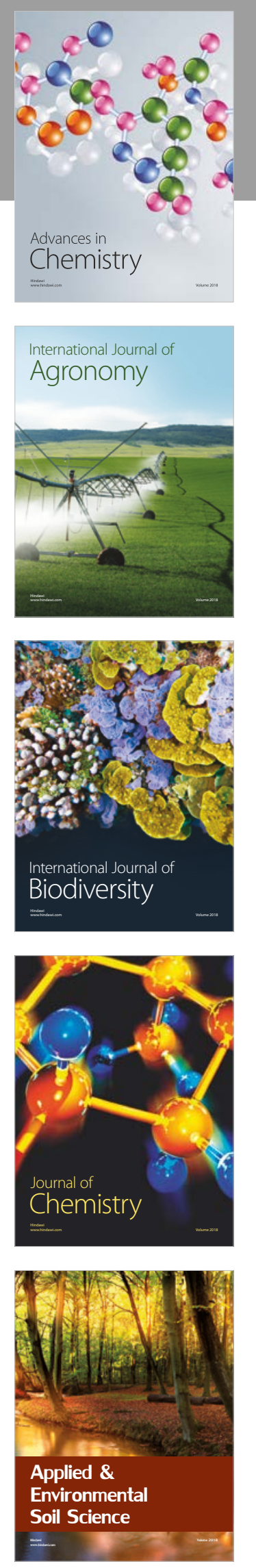

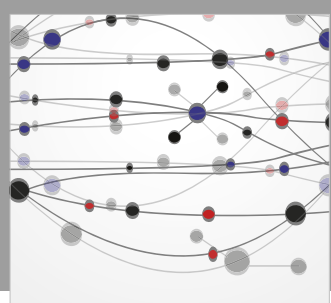

The Scientific World Journal

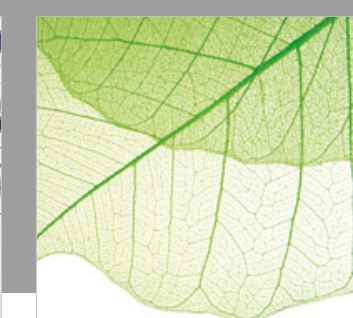

Journal of Botany

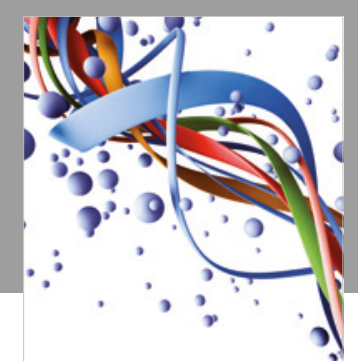

Scientifica

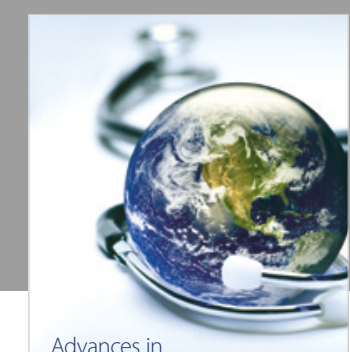

Public Health

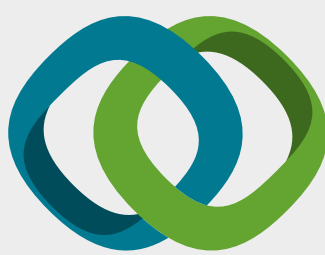

Hindawi

Submit your manuscripts at

www.hindawi.com
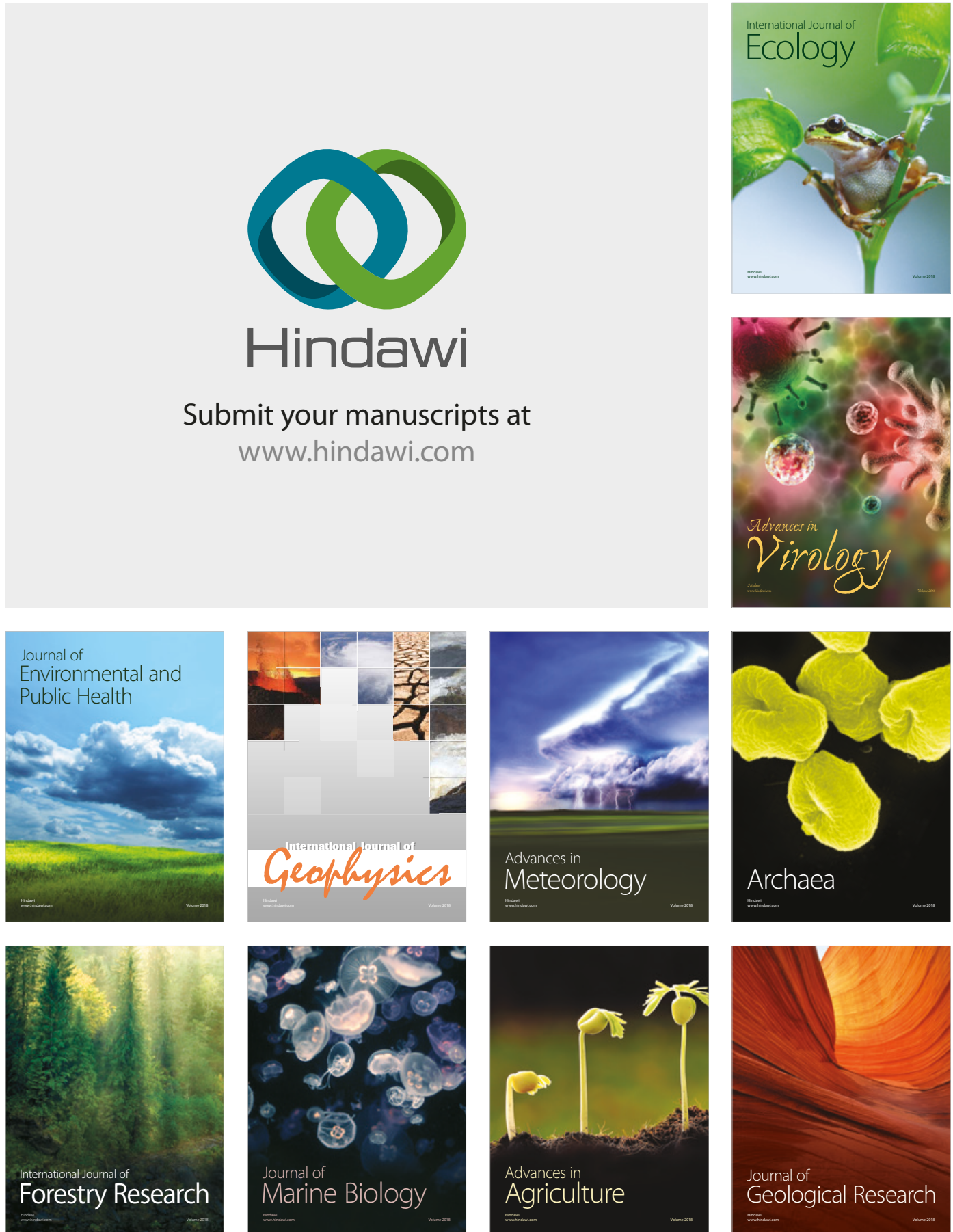

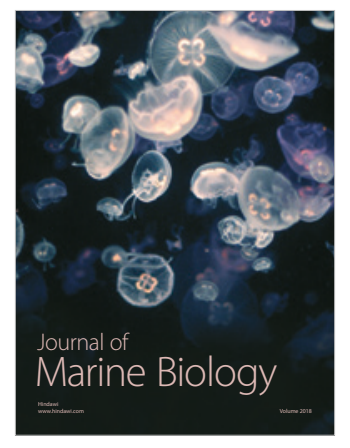

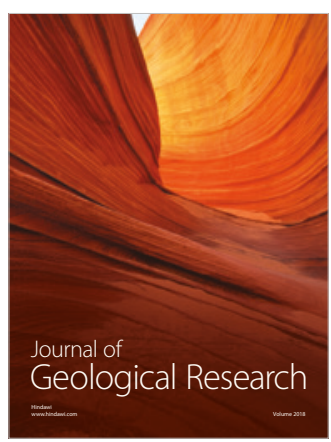

